\title{
HER2-directed antibodies, affibodies and nanobodies as drug-delivery vehicles in breast cancer with a specific focus on radioimmunotherapy and radioimmunoimaging
}

\author{
Betül Altunay ${ }^{1} \cdot$ Agnieszka Morgenroth $^{1} \cdot$ Mohsen Beheshti $^{1,2,3} \cdot$ Andreas Vogg $^{1} \cdot$ Nicholas C. L. Wong $^{4}$. \\ Hong Hoi Ting ${ }^{4}$. Hans-Jürgen Biersack ${ }^{5}$ Elmar Stickeler ${ }^{2,6} \cdot$ Felix M. Mottaghy $^{1,2,7}$ (D)
}

Received: 26 August 2020 / Accepted: 26 October 2020 / Published online: 12 November 2020

(C) The Author(s) 2020

\begin{abstract}
Purpose The aim of the present paper is to review the role of HER2 antibodies, affibodies and nanobodies as vehicles for imaging and therapy approaches in breast cancer, including a detailed look at recent clinical data from antibody drug conjugates and nanobodies as well as affibodies that are currently under development.

Results Clinical and preclinical studies have shown that the use of monoclonal antibodies in molecular imaging is impaired by slow blood clearance, associated with slow and low tumor uptake and with limited tumor penetration potential. Antibody fragments, such as nanobodies, on the other hand, can be radiolabelled with short-lived radioisotopes and provide highcontrast images within a few hours after injection, allowing early diagnosis and reduced radiation exposure of patients. Even in therapy, the small radioactively labeled nanobodies prove to be superior to radioactively labeled monoclonal antibodies due to their higher specificity and their ability to penetrate the tumor.

Conclusion While monoclonal antibodies are well established drug delivery vehicles, the current literature on molecular imaging supports the notion that antibody fragments, such as affibodies or nanobodies, might be superior in this approach.
\end{abstract}

Keywords HER2 $\cdot$ Antibody drug conjugate $\cdot$ Nanobody $\cdot$ Single domain antibody $\cdot$ Affibody $\cdot$ Immunotherapy

Betül Altunay and Agnieszka Morgenroth contributed equally to this work.

This article is part of the Topical Collection on Theragnostic

Felix M. Mottaghy

fmottaghy@ukaachen.de

1 Department of Nuclear Medicine, University Hospital Aachen, RWTH Aachen University, 52074 Aachen, Germany

2 Center of Integrated Oncology (CIO), Universities of Aachen, Bonn, Cologne and Düsseldorf, Kerpener Str. 62, 50937 Cologne, Germany

3 Division of Molecular PET-Imaging and Theranostics, Paracelsus Medical University, Salzburg 5020, Austria

4 Nanomab Technology Limited, Shanghai, People's Republic of China

5 Department of Nuclear Medicine, University Hospital Bonn, Bonn, Germany

6 Department of Gynecology and Obstetrics, RWTH Aachen, Aachen, Germany

7 Department of Radiology and Nuclear Medicine, Maastricht University Medical Center (MUMC+), 6202 Maastricht, The Netherlands

$\begin{array}{ll}\text { Abbreviations } & \\ \text { ADC } & \text { Antibody drug conjugate } \\ \text { ADIBO } & N \text {-(3-aminopropionyl)-5, } \\ & \text { 6-dihydro-11, } \\ & \text { 12-didehydrodibenzo[b,f]azocine } \\ \text { ASCO } & \text { American Society of Clinical Oncology } \\ \text { AuNP } & \text { Gold nanoparticles } \\ \text { CAP } & \text { College of American Pathologists } \\ \text { CDR } & \text { Complementarity determining regions } \\ \text { CH2 } & \text { Constant heavy 2 } \\ \text { DAR } & \text { Drug to antibody ratio } \\ \text { DFO } & \text { Deferoxamine } \\ \text { DS8201 } & \text { Trastuzumab deruxtecan } \\ \text { EMA } & \text { European Medicines Agency } \\ \text { ER } & \text { Estrogen } \\ \text { FDA } & \text { Food and Drug Administration } \\ \text { FISH } & \text { Fluorescence in situ hybridization } \\ \text { HcAb } & \text { Heavy chain antibody } \\ \text { HER2 } & \text { Human epidermal growth factor } \\ & \text { receptor 2 } \\ \text { IA } & \text { Injected activity }\end{array}$




$\begin{array}{ll}\text { ID } & \text { Injected dose } \\ \text { IHC } & \text { Immunohistochemistry } \\ \text { MMAF } & \text { Monomethylauristatin F } \\ \text { NOTA } & 1,4,7 \text {-triazacyclononane-1,4 } \\ & \text { 7-triacetic acid } \\ \text { OS } & \text { Overall survival } \\ \text { PEG } & \text { Polyethylene glycol } \\ \text { PET } & \text { Positron emission tomography } \\ \text { PFS } & \text { Progression-free survival } \\ \text { PR } & \text { Progesteron } \\ \text { p-SCN-Bn-NOTA } & \text { S-2-(4-isothiocyanatobenzyl)- } \\ & \text { 1,4,7-triazacyclononane-1,4 } \\ & \text { 7-triacetic acid } \\ \text { RC-48 } & \text { Hertuzumab Vedotin/ } \\ & \text { Disitamab Vedotin } \\ \text { scFV } & \text { Single chain variable fragment } \\ \text { sdAb } & \text { Single domain antibody } \\ \text { SGMIB } & \text { N-succinimidyl } \\ & \text { 4-guanidinomethyl-3-iodobenzoate } \\ \text { SPAAC } & \text { Strain-promoted azide-alkyne } \\ & \text { cycloaddition (SPAAC) } \\ \text { SPECT } & \text { Single photon emission } \\ \text { computed tomography } \\ \text { SYD985 } & \text { [vic-] Trastuzumab Duocarmycin } \\ \text { T-DM1 } & \text { Ado-trastuzumab emtansine } \\ \text { vc-seco-DUBA } & \text { Valine-citrulline-seco } \\ & \text { DUocarmycin hydroxyBenzamide- } \\ & \text { Azaindole } \\ \text { VHH } & \text { Variable domain of camelid heavy } \\ \text { chain antibody } \\ \text { VNAR } & \text { Variable domain of the shark new } \\ & \text { antigen receptor } \\ & \end{array}$

\section{Introduction}

Breast cancer is the second most common cancer worldwide and the most frequent among women with an estimated 2.09 million new cases diagnosed in 2018 (11.6\% of all cancers). It is the fourth cause of death from cancer overall and the leading cause of cancer death in women [1].

The general subtyping of breast cancer is based on the presence of transmembrane and intracellular receptors, namely, estrogen (ER), progesterone (PR) and the human epidermal growth factor receptor 2 (HER2, also referred to as ERBB2) $[2,3]$. While reviews from previous years reported that approximately $25-30 \%$ of breast carcinomas show an overexpression of the oncoprotein HER2, the IQTIG sets the rate for Germany in 2019 at about $13 \%$. The overexpression is due to the 2 - to greater than 20-fold amplification of the protooncogene c-erbB2 $[4,5]$. According to the guidelines of the American Society of Clinical Oncology (ASCO)/ College of American Pathologists (CAP), the HER2 status can be divided into four categories by using immunohistochemistry (Fig. 1).

If no cells are stained or only a weak, barely perceptible membrane staining is present, the status is referred to as HER2 negative (score 0 and $1+$ ). Score $2+$, means an equivocal status, applies if a weak to moderate complete membrane staining can be observed in more than $10 \%$ of tumor cells. HER2 positive (score $3+$ ) is defined as a complete, intensive staining of the circumferential membrane that occurs in more than $10 \%$ of tumor cells [7].

Several studies showed that the amplification of this tumorassociated antigen has a direct role in the pathogenesis of cancer [8-11]. This is because the HER2 receptor is activated by homo-/heterodimerisation and consequently triggers many important downstream signals, including the Mitogenactivated protein kinase (MAPK) and phosphoinositide 3kinase (PI3K) signalling pathways. The signalling cascades recruit and regulate various proteins that, among other biological and clinical parameters, stimulate cell proliferation and survival. However, if the HER2 receptor is overexpressed, the cell cycle is disrupted and tumorigenesis is promoted [12]. Therefore, the higher HER2 is expressed, the lower the disease-free survival, the higher the risk of metastases and the shorter the overall survival (OS) rate $[13,14]$.

The introduction of monoclonal antibodies against the extracellular domain of the HER2 protein was considered a breakthrough in breast cancer therapy. The antitumor efficacy of HER2-directed antibodies is attributed besides the blockade of the HER2 pathway to the broad activation of the immune system, which leads to antibody-dependent cellular cytotoxicity [15]. Trastuzumab was the first humanized monoclonal antibody approved by the Food and Drug Administration (FDA) of the USA in 1998 and two years later by the European Medicines Agency (EMA) for the treatment of both early stage and metastatic HER2 overexpressing breast cancer $[13,16,17]$. In the clinic, trastuzumab is always combined with standard chemotherapy as a starting treatment in the neoadjuvant, adjuvant and metastatic setting, respectively. In all clinical situations, the outcome for patients cotreatment of trastuzumab was dramatically improved with reduced recurrence and improved disease-free survival rates but also improved overall survival in the metastatic situation (median survival, 25.1 vs. 20.3 months)[18-21]. The antibody's remarkable activity and the favourable cytotoxicity profile achieved by its high binding specificity made it a favourable vehicle for carriers of other, less specific anti-cancer drugs [22, 23].

\section{Antibody drug conjugates targeting HER2}

The goal in the development of antibody drug conjugates (ADC) is to achieve increased cytotoxicity in the target 

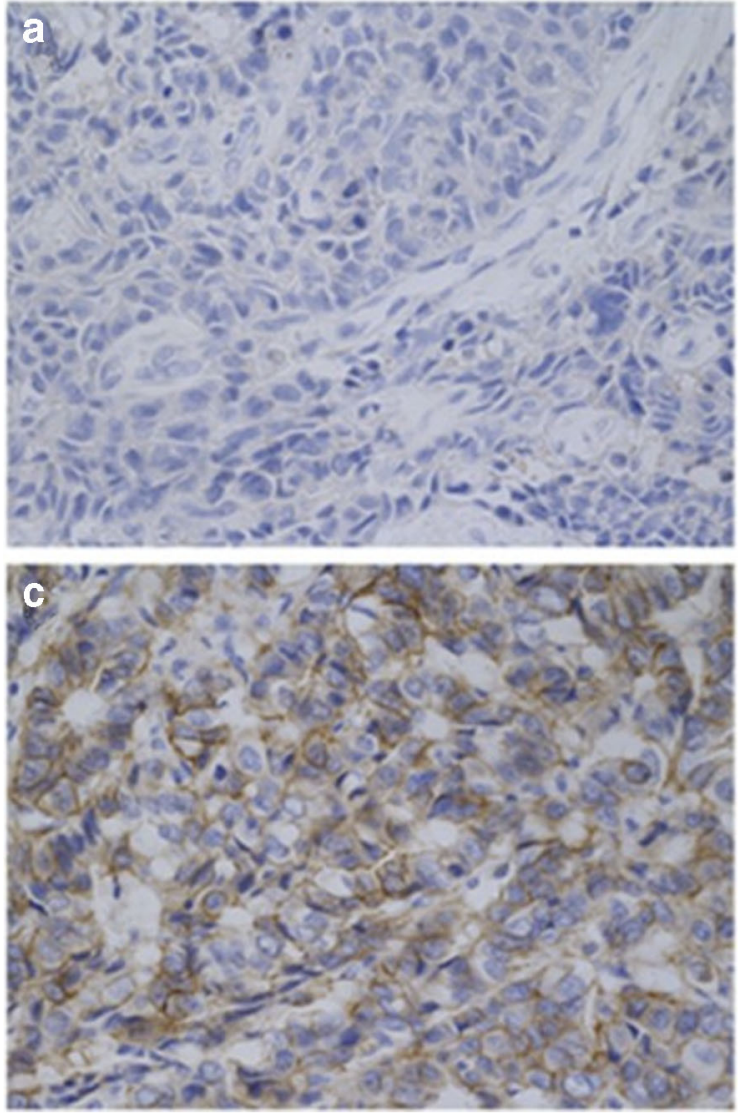

Fig. 1 HER2 (human epidermal growth factor receptor 2) expression status determined by immunohistochemistry (IHC). Depicted are tissues from patients with invasive breast cancer (400x) whose HER2 status was
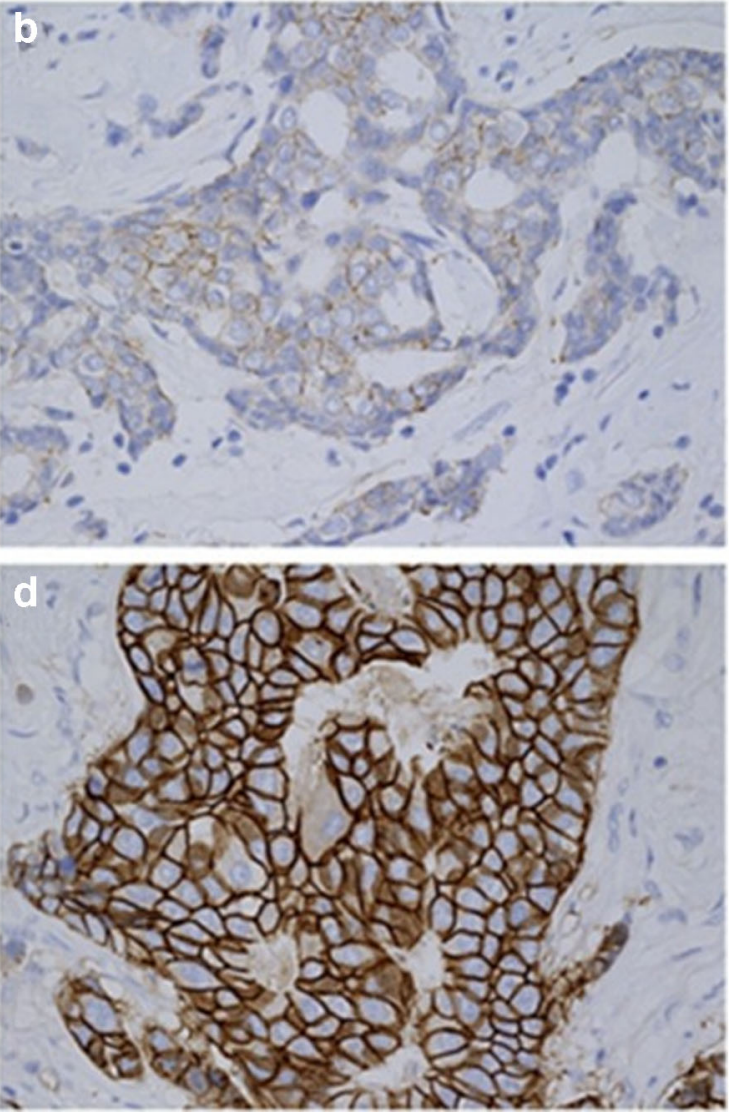

determined by IHC. a Negative (score 0 ), b negative (score $1+$ ), $\mathbf{c}$ equivocal (score 2+), d positive (score 3+). [6]

conjugate with a diffusible drug can be cleaved by extracellular enzymes prior to internalization of a diffusible drug (Fig. 2a) [26].

Besides monoclonal antibodies, antibody fragments can also be used as vehicles for ADCs. Antibody fragments such as minibodies, diabodies, single chain fragments of variable regions (scFvs) and nanobodies are parts of antibodies, modified through genetic engineering. They usually contain only the basic targeting and binding domain of antibodies. Due to their relatively small molecular weight $(7-100 \mathrm{kDa})$ and low complexity, the antibody fragments exhibit better pharmacokinetics for non-invasive targeted imaging. In addition, their properties such as shorter circulation times, deeper tumor penetration and high specificity to the target make them preferable to monoclonal antibodies as vehicles for ADCs [27]. Affibody molecules are one of the most important engineered proteins for molecular imaging. The small antigen-binding domain is derived from Staphylococcal Protein A (SPA) and has a molecular weight of 6-7 kDa. Other much-researched antigen binding domains are nanobodies, which represent an antibody fragment consisting of a single monomeric variable neighbouring cells. Alternatively, the ADC-payload 


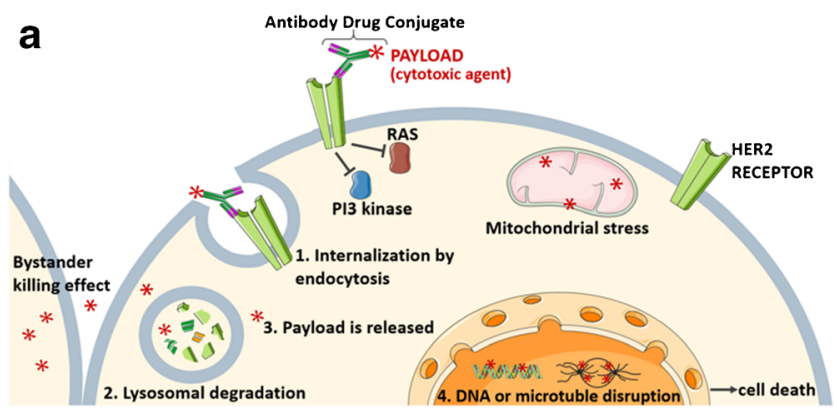

Fig. 2 Mode of action of HER2-directed antibody drug conjugates with a $\mathbf{a}$ cytotoxic agent and $\mathbf{b}$ radiopharmaceutical payload. By binding of the antibody conjugate, the activation of the receptor and thus the

antibody domain and are characterised by their low molecular weight of approximately $15 \mathrm{kDa}$ and their fast blood clearance [28].

Currently, several ADCs targeting HER2 are under clinical investigation for breast cancer treatment.

\section{HER2 targeting monoclonal antibodies conjugated to a chemotherapeutic agent}

Ado-trastuzumab emtansine (T-DM1, KADCYLA $®$ ) is the first EMA and FDA-approved ADC which targets HER2. It consists of trastuzumab connected to 3.5 molecules of DM-1 (mertansine or emtansine, derivatives of maytansine and potent microtubule inhibitors) by a non-cleavable linker $[25,29]$. A phase I study published in 2010 was the first study demonstrating the safety and tolerability of T-DM1 [30]. In subsequent randomized phase III studies, the efficacy of this ADC therapy as adjuvant, neoadjuvant, firstline and second-line therapy in HER2-positive breast cancer was evaluated. The outcome of the TH3RESA (NCT01419197) and EMILIA study (NCT00829166) in patients with HER2-positive metastatic breast cancer previously treated with trastuzumab and a taxane demonstrated improvements in median OS (30.9 months vs. 25.1 months) and progression-free survival (PFS) (9.6 months vs. 6.4 months) in the T-DM1-treated group compared with lapatinib and capecitabine treated groups $[31,32]$. On the other hand, the low efficacy of ADC in combination with pertuzumab in the MARIANNE and KRISTINE studies [33] led to the discontinuation of the KAITLIN study (NCT01966471), which was designed to evaluate the efficacy and safety of T-DM1 in combination with pertuzumab and a taxane as adjuvant therapy after anthracycline-based chemotherapy in participants with HER2-positive primary invasive breast cancer. A metaanalysis reported that the most common adverse events of all-grade in patients receiving T-DM1 include fatigue, nausea, musculoskeletal pain, hemorrhage, thrombocytopenia, headache, increased transaminases, constipation and epistaxis. The main toxicities of T-DM1 are considered to be

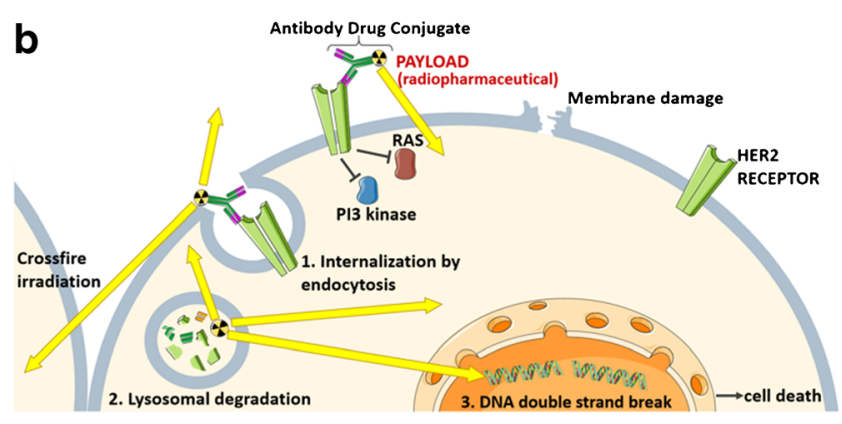

intracellular signalling cascade is inhibited. After internalization and lysosomal degradation of the antibody receptor complex, the payload is released in the cytoplasm where it exerts its effect

caused by the payload, but further research is needed [34]. Most of these adverse events are generally of low grade and manageable, except for severe thrombocytopenia (grade $\geq 3$ ). For this reason, patients with severe cardiac dysfunction, increased liver enzymes, or in cases of severe thrombocytopenia should have their dose adjusted or treatment with T-DM1 discontinued $[35,36]$.

Another recently approved ADC is trastuzumab deruxtecan (DS8201, Enhertu®), which is a humanized trastuzumab antibody conjugated with a topoisomerase I inhibitor (DXd, an exatecan derivative). The drug to antibody ratio (DAR) is approximately eight higher than in all currently approved ADCs $[37,38]$. In preclinical models, DS8201 was shown to be well tolerated and able to overcome T-DM1 resistance $[25,39,40]$. A major advantage of this ADC is that it is effective at different levels of HER2 expression [41]. FDA approval of this ADC was granted after demonstrating antitumor efficacy and safety in a phase II dose-finding study (DESTINY-Breast01, NCT03248492) in patients with HER2-positive, unresectable and/or metastatic breast cancer after two or more anti-HER2 therapy cycles [42]. Currently, eight registered ongoing trials investigating DS8201 are recruiting (NCT04042701, NCT03523572, NCT03505710, NCT04132960, NCT04014075, NCT03523585, NCT03529110, NCT03734029). The results of these studies are unpublished yet, but based on the findings of previous studies, treatment with DS8201 could be a valuable therapy option with the potential to address the T-DM1 insensitive breast cancer and other HER2 expressing cancers.

Other ADCs consisting of a monoclonal antibody and a cytotoxic agent, which are currently being investigated in clinical trials, are summarized in Table 1.

Several other HER2-targeting ADCs are currently undergoing preclinical trials for example LCB14-0110. This ADC is composed of monoclonal HER2 directed antibody trastuzumab linked via a beta-glucuronide linker to monomethylauristatin F (MMAF). However, no data have been published so far [43]. Another ADC which is currently investigated in preclinical studies is MI30004. This ADC consists of a humanized trastuzumab antibody 
Table 1 Overview of human trials of HER2 targeting non-approved immunotherapeutic conjugates, their composition and their current state of development. Status of April 2020

\begin{tabular}{|c|c|c|c|c|c|c|c|}
\hline $\mathrm{ADC}$ & Antibody & Payload & Trial no. & Phase & Patients & $\begin{array}{l}\text { First } \\
\text { posted }\end{array}$ & Status \\
\hline \multirow[t]{3}{*}{ BAT8001 } & \multirow[t]{3}{*}{ Trastuzumab } & \multirow[t]{3}{*}{ Maytansine derivative } & NCT04189211 & I & 30 & $12 / 2019$ & $\begin{array}{l}\text { Active, not } \\
\text { recruiting }\end{array}$ \\
\hline & & & NCT04151329 & $\mathrm{I} / \mathrm{II}$ & 72 & $11 / 2019$ & $\begin{array}{l}\text { Enrolling by } \\
\text { invitation }\end{array}$ \\
\hline & & & NCT04185649 & III & 410 & $12 / 2019$ & $\begin{array}{l}\text { Active, not } \\
\text { recruiting }\end{array}$ \\
\hline \multirow{4}{*}{$\begin{array}{l}\text { [vic-] Trastuzumab Duocarmycin } \\
\text { (SYD985) }\end{array}$} & \multirow[t]{4}{*}{ Trastuzumab } & \multirow[t]{4}{*}{ vc-seco-DUBA } & NCT02277717 & I & 185 & $10 / 2014$ & Completed \\
\hline & & & NCT04235101 & I & 120 & $01 / 2020$ & Recruiting \\
\hline & & & NCT04205630 & II & 60 & $12 / 2019$ & Recruiting \\
\hline & & & NCT03262935 & III & 345 & $08 / 2017$ & Recruiting \\
\hline \multirow[t]{10}{*}{ Hertuzumab Vedotin (RC-48) } & \multirow[t]{10}{*}{ Hertuzumab } & \multirow[t]{10}{*}{ Monomethylauristatin E } & NCT02881190 & I & 57 & $08 / 2016$ & Completed \\
\hline & & & NCT02881138 & $\mathrm{I}$ & 50 & $08 / 2016$ & Recruiting \\
\hline & & & NCT04311034 & I & 36 & $03 / 2020$ & Recruiting \\
\hline & & & NCT03052634 & $\mathrm{I} / \mathrm{II}$ & 90 & $02 / 2017$ & Recruiting \\
\hline & & & NCT04264936 & $\mathrm{I} / \mathrm{II}$ & 36 & $02 / 2020$ & Recruiting \\
\hline & & & NCT04329429 & II & 57 & $04 / 2020$ & Recruiting \\
\hline & & & NCT03809013 & II & 60 & $01 / 2019$ & Recruiting \\
\hline & & & NCT04073602 & II & 18 & 08/2019 & Recruiting \\
\hline & & & NCT03556345 & II & 127 & $06 / 2018$ & $\begin{array}{l}\text { Active, not } \\
\text { recruiting }\end{array}$ \\
\hline & & & NCT03500380 & II & 228 & $04 / 2018$ & Recruiting \\
\hline \multirow[t]{2}{*}{ MM-302 } & \multirow{2}{*}{$\begin{array}{l}\text { PEGylated } \\
\text { antibody }\end{array}$} & \multirow[t]{2}{*}{ Liposomal doxorubicin } & NCT01304797 & I & 75 & $02 / 2011$ & Unknown \\
\hline & & & NCT02213744 & II / III & 113 & $08 / 2014$ & Terminated \\
\hline ARX788 & $\begin{array}{r}\text { Anti HER2 } \\
\text { antibody }\end{array}$ & Amberstatin 269 & NCT03255070 & I & 60 & $08 / 2017$ & Recruiting \\
\hline XMT-1522 & HT-19 & $\begin{array}{l}\text { Auristatin } \\
\text { F-hydroxypropylamide }\end{array}$ & NCT02952729 & I & 120 & $11 / 2016$ & $\begin{array}{l}\text { Active, not } \\
\text { recruiting }\end{array}$ \\
\hline MEDI4276 & $\begin{array}{l}\text { bi-paratopic } \\
\text { antibody }\end{array}$ & AZ13599185 & NCT02576548 & $\mathrm{I} / \mathrm{II}$ & 47 & $10 / 2015$ & Completed \\
\hline DHES0815A & $\begin{array}{c}\text { Trastuzumab } \\
\text { derivative }\end{array}$ & pyrrolobenzodiazepine & NCT03451162 & I & 14 & $03 / 2018$ & $\begin{array}{l}\text { Active, not } \\
\text { recruiting }\end{array}$ \\
\hline BDC-1001 & Trastuzumab & TLR7/8 agonist & NCT04278144 & I & 390 & $02 / 2020$ & Recruiting \\
\hline ALT-P7 (HM2-MMAE) & HM2 & monomethylauristatin $\mathrm{E}$ & NCT03281824 & I & 30 & 09/2017 & Recruiting \\
\hline ADCT-502 & Trastuzumab & Tesirine & NCT03125200 & I & 21 & $04 / 2017$ & Terminated \\
\hline PF-06804103 & $\begin{array}{r}\text { Anti HER2 } \\
\text { antibody }\end{array}$ & Auristatin-0101 & NCT03284723 & I & 124 & 09/2017 & Recruiting \\
\hline
\end{tabular}

connected by a noncleavable linker to two molecules of payload PM050489, which binds to $\beta$-tubulin with very high affinity and disrupts the microtubule network, resulting in mitotic aberrations and cell death. In vitro and in vivo analyses of MI130004 in different tumor cell lines, including breast, ovarian and gastric cancer, showed that MI130004 generated a long-lasting antitumor effect with a statistically significant inhibition of tumor growth and increased the median survival time compared to treatment with trastuzumab. Its therapeutic efficacy still has to be evaluated in a clinical trial [44].

\section{Radiolabeled HER2 targeting monoclonal antibodies}

Radiopharmaceuticals can also be used as a payload in ADCs. The intravenous or intratumoral injection of a monoclonal antibody tightly labeled with a radionuclide is called radioimmunotherapy or immunoimaging, depending on the purpose. The specific binding of the antibodies to their target allows a direct transport of the radionuclide to the tumor and leads to cell death through radiation-induced double strand DNA breaks and the formation of reactive oxygen species in the case of beta-, alpha or Auger electron-emitters 
(Fig. 2b) or enables targeted molecular imaging (immunoimaging). The efficacy of radioimmunotherapy depends on the radiation quality or linear energy transfer (LET), which refers to the amount of deposited energy per unit track length. The $\beta$-emitters produce a low LET radiation of about $0.2 \mathrm{keV} / \mu \mathrm{m}$, release energies of $30 \mathrm{keV}$ and $2.3 \mathrm{MeV}$ and have a long range within the tissue $(0.5-12 \mathrm{~mm})$ thus causing a crossfire effect. $\alpha$-emitters, on the other hand, can produce high LET radiation of 50-230 keV/ $\mu \mathrm{m}$ with energies of 5 to $9 \mathrm{MeV}$, but have a much shorter range in tissue $(50-100 \mu \mathrm{m})$. This reduces the toxicity of $\alpha$-emitters compared to $\beta$-emitters to neighbouring cells and increases the number of ionisations per emission. Auger electron emitters are characterised by a medium LET radiation (4-26 keV/ $\mu \mathrm{m}$ ) with energies between $1 \mathrm{eV}$ and $1 \mathrm{keV}$ and a range in tissue of less than $1 \mu \mathrm{m}$, but a high emission density. This results in an intensive energy deposition within a nanometer range, thus requiring the deposition of Auger electron radiation to the cell DNA. The therapeutic effect is achieved by inducing severe DNA damage [45, 46]. Due to the different properties of the emitters, the effectiveness of radioimmunotherapy to a large extent depends on the selection of the isotope. By applying other radionuclides with comparable chemical properties the same labeling precursor or radiopharmaceutical can be used for both, molecular imaging and therapy, which represents the concept of theranostics [47]. For molecular imaging, gamma emitting or positron-emitting radionuclides are applied for single photon emission computed tomography (SPECT) or positron emission tomography (PET) respectively [48]. For both, radiolabeling and purification purposes by immobilised metal affinity chromatography, a C-terminal amino acid tag can be inserted genetically into the antibody or its fragment [49]. Depending on the chosen radionuclide, radiolabeling of antibodies requires an additional chelating agent for complexation or a prosthetic group for electrophilic substitution. Several conjugation strategies have been described therefore [50-53]. It shall not be underestimated, that the type and placement of the chelator can influence the tumor-targeting properties, the blood clearance rate and uptake into healthy tissue of the antibody [54]. By enabling early detection, realtime therapeutic monitoring and the ability to streamline drug development, molecular imaging is preferable to invasive tissue sampling, which is usually limited to a single time point and cannot capture tumor heterogeneity [55].

Up to date, numerous investigations with radiolabeled monoclonal antibodies that address HER2 have been conducted. The positron emitting zirconium-89 labeled trastuzumab is one of the most investigated. For this purpose the radiometal is linked to the antibody via the chelator DFO (deferoxamine). Although animal studies have shown that this chelator is not stable leading to the release of the radiometal during circulation and it's accumulation in bones (15-20\% injected dose per gram [ID/g]) [56], this phenomenon has not been observed in clinical studies [57]. Nevertheless, several attempts have been made to find a new chelator. However, none of the tested chelators L1-L4, which are based on hydroxamatefunctionalized macrocycles, showed improved in vivo stability $[58,59]$. Nevertheless, already in the first clinical trial with ${ }^{89} \mathrm{Zr}$-Df-Bz-NCS-trastuzumab in patients with HER2-positive metastatic breast cancer, a high tumor uptake $(33.4 \pm 7.6 \% \mathrm{ID} /$ $\mathrm{g}$ ) including a depiction of metastases was achieved [60]. Two other clinical trials (NCT01832051, NCT01565200) have shown the potential of imaging HER2 with ${ }^{89} \mathrm{Zr}$-trastuzumab. While one study demonstrated that ${ }^{89} \mathrm{Zr}$-trastuzumab supports clinical decision making when HER2 status could not be determined by standard procedures (bone scan, ${ }^{18}$ F-FDG PET, CT and biopsy), the other study was able to determine tumor heterogeneity. This allows the selection of a personalized therapy $[61,62]$. In a further phase I clinical trial (NCT02065609) the liver was determined as the dose-limiting organ at a dose of $1.63 \mathrm{mSv} / \mathrm{MBq}$. Since only slow blood clearance with a biological half-life of $113 \mathrm{~h}$ and an initial level of 58\% ID in the blood pool was observed, imaging with ${ }^{89} \mathrm{Zr}$-trastuzumab was considered safe with acceptable but not satisfactory dosimetry [63]. In another phase I clinical trial (UMIN000004170), the copper-64 labeled ADC, ${ }^{64} \mathrm{Cu}-$ DOTA-trastuzumab, proved to be safe and effective in identifying HER2-positive lesions in patients with primary and metastatic breast cancer when high liver uptake was reduced by administration of $45 \mathrm{mg}$ cold trastuzumab. Although the HER2 specificity was confirmed by autoradiography, immunohistochemistry scores and LC-MS/MS, the relationship between HER2 PET imaging and the effects of anti-HER2 therapy still need to be evaluated [64-66]. Bhusari et al. were able to show the safety of lutetium-177 labeled trastuzumab, as a radioimmunoconjugate, in a phase I clinical trial. The authors reported also specific tracer uptake in the HER2-positive primary and metastatic breast lesions. Due to a high uptake the liver is considered to be the dose-limiting organ (tumor to background ratio of 0.38 on day 1 ). ${ }^{177}$ Lu-trastuzumab may be used for palliative purpose in combination with other conventional treatments for HER2-positive metastatic breast cancer, but further clinical trials with escalating antibody doses and dosimetric evaluation are needed [67].

In the area of radioactively labeled ADCs, an attempt is made to label the antibody trastuzumab with other radioisotopes, such as indium-111 [68-70], technetium-99m [71], rhenium-188 [72-75], thorium-227 [76] or iodine-131 [77]. In a preclinical study for example, Li et al. were able to show that ${ }^{111}$ In-trastuzumab-NLS (Nuclear Localizing Signal) can modulate the NF-KB signalling pathway. They also showed that the coinjection of bortezomib can inhibit the growth of HER2 overexpressing breast cancer SK-BR-3 cells [68]. In another study, the ${ }^{111}$ In-trastuzumab was linked to gold nanoparticles (AuNP). These specifically bound to HER2 positive SK-BR-3 cells and caused lethal DNA double-strand breaks. 
In mice with subcutaneous HER2-positive breast cancer xenografts, an intratumoral injection of trastuzumab AuNP- ${ }^{111}$ In inhibited tumor growth without obvious normal tissue toxicity [69]. To our knowledge, there is no clinical study comparing radiolabeled trastuzumab with unlabeled trastuzumab. However, preclinical studies have shown that a 5-fold increase in toxicity of ${ }^{177} \mathrm{Lu}$-DOTA-trastuzumab compared to unlabeled trastuzumab was observed in SK-BR-3 cells (relative number of survived cells after 120 h $10 \pm 3.5 \%$ vs. $41 \pm 2.8$ $\%$ ) [78]. In two further studies, the higher cytotoxic potency of ${ }^{111}$ In labeled trastuzumab derivatives - making use of the therapeutic Auger electron emission - compared to unlabeled trastuzumab was shown in vitro. While ${ }^{111}{ }^{1 n}-N_{L} S_{6-}$ trastuzumab was 6 times more effective at killing SK-BR-3 cells than the cold antibody (relative number of survived cells $10.5 \pm 2.1 \%$ vs. $64.6 \pm 3.0 \%$ ) [79], the administration of ${ }^{111}$ In-Hy-MCP trastuzumab with a high specific activity showed a 20.5-fold higher cytotoxic potency (relative number of survived cells $1.8 \pm 1.3 \%$ vs. $37.0 \pm 5.3 \%$ ) [80]. This shows that radioactively labeled antibodies can be more effective in treating tumors than unlabeled ones and that further research in this area is needed.

Further research is also conducted on the radiolabeling of the antibody pertuzumab. Preclinical studies have shown that ${ }^{64} \mathrm{Cu}$-NOTA pertuzumab is a good PET tracer that specifically targets HER2 receptors in breast cancer xenografts in NOD/ SCID mice [81, 82]. This could also be demonstrated for ${ }^{89} \mathrm{Zr}-$ pertuzumab [83]. In addition, Marquez et al. show for this radioconjugate that increased tumor uptake also occurs when co-injected with trastuzumab [83]. In the field of radioimmuntherapy ${ }^{177} \mathrm{Lu}$-pertuzumab was investigated. Persson et al. demonstrated the good intracellular retention of the radiolabeled antibody, both in vitro and in vivo, and its HER2 specific binding [84, 85].

\section{Disadvantages of HER2 addressing therapeutic monoclonal antibodies}

Monoclonal antibodies such as trastuzumab or pertuzumab are often used as vehicles for the specific administration of a therapeutic drug to its target due to their specificity and affinity for their antigen. Even though their use in breast cancer therapy was initially very successful, there are still insurmountable limitations associated with their use in targeted therapy. The relatively high molecular weight $(\sim 160 \mathrm{kDa})$ of antibodies, the heterogeneous blood perfusion, the hindered diffusion in the interstitium, the extravascular binding of monoclonal antibodies and the increased interstitial pressure (turgor effect) leads to a heterogeneous distribution of the antibodies in the tumor. Also, due to their large molecular size, antibodies cannot be filtered by the kidney and accumulate in the liver, leading to hepatotoxicity [86-88]. In addition, it has been shown that the high affinity of the antibodies impedes homogeneous tumor penetration and intratumoral diffusion, as the agent can get stuck at the periphery $[89,90]$. This incomplete tumor penetration leads to a suboptimal therapeutic efficiency, which is one of the reasons for the development of resistance to antibody-based therapy [91]. Another disadvantage is slow blood clearance of monoclonal antibodies that lasts between few days and weeks, whereby good contrast images, which are achieved by a high tumor to background ratio, can only be obtained after hours or days after application. For this reason, radiolabeling with long-lived radionuclides is necessary. Moreover, monoclonal antibodies show a considerable degree of non-specific uptake at the target sites, especially at the earlier time-points, and can only be administered intravenously or subcutaneously due to their low thermodynamic stability $[60,92,93]$. For ADCs to activate their antibody-dependent cell-mediated cytotoxicity (ADCC), it is desirable that the antibody-antigen complex is not rapidly internalized. However, phagocytosis is mediated by the Fc region of the antibody, thereby reducing the availability of the antibody on the cell surface to unfold its desired mechanism of action $[94,95]$. In addition, only few antibodies are able to cross the blood-brain barrier and reach the central nervous system, making it difficult to detect and treat brain metastases. These limitations have initiated and driven the development of smaller antibody fragments as vehicles with better tissue penetration and higher cytotoxic efficacy [96].

\section{Affibodies}

Affibodies (Affibody ${ }^{\circledR}$ ) are technically produced antibody fragments that can be used as theranostic tools. Affibodies derived from Staphylococcal surface protein A form a cysteine-free three-helix scaffold protein consisting of $58 \mathrm{ami}-$ no acids and contain no disulfide bridges, thus increasing the stability of the molecule. Due to their high affinity and tolerance to chemicals, higher temperatures and extreme $\mathrm{pH}$ values, as well as their small size and short circulation time, affibody molecules are very well suited for a use in molecular imaging [97].

After preclinical studies [98-101] showed successful tumor targeting and imaging for HER2-directed affibody molecules, they were further investigated in clinical trials (Table 2). The results of the first clinical trial with the radiolabeled HER2targeting affibody ABY-002 (DOTA ZHER2:342 pep2) in patients with recurrent breast cancer were very promising (EudraCT 2007002530 11). With the indium-111- and gallium-68 labeled ABY-002, high-quality SPECT and PET images, respectively, could be acquired after only $2 \mathrm{~h}$ postinjection (p.i.). The majority of lesions previously detected with ${ }^{18}$ F-FDG-PET could be confirmed with the radioactive affibody. Only those near the kidney and liver could not be detected due to the high background uptake [102]. Therefore, 
Table 2 Overview of human trials of HER2 targeting affibodies in breast cancer patients. Status of April 2020

\begin{tabular}{|c|c|c|c|c|c|c|c|}
\hline Affibody & Radioisotope & $\begin{array}{l}\text { Diagnostic/ } \\
\text { therapy }\end{array}$ & Trial no. & Phase & Patients & First posted & Reference \\
\hline ABY-002 & $\begin{array}{l}{ }^{68} \mathrm{Ga} \\
{ }^{111} \mathrm{In}\end{array}$ & $\begin{array}{l}\text { PET } \\
\text { SPECT }\end{array}$ & EudraCT 200700253011 & Pilot study & 3 & $07 / 2007$ & {$[102]$} \\
\hline \multirow[t]{4}{*}{ ABY -025} & ${ }^{111} \mathrm{In}$ & SPECT & NCT01216033 & $\mathrm{I} / \mathrm{II}$ & 7 & $10 / 2010$ & [103] \\
\hline & ${ }^{68} \mathrm{Ga}$ & PET & NCT02095210 & I & 8 & 03/2014 & [104] \\
\hline & & & NCT01858116 & $\mathrm{I} / \mathrm{II}$ & 16 & $05 / 2013$ & [105] \\
\hline & & & NCT03655353 & $\mathrm{II} / \mathrm{III}$ & 120 & $08 / 2018$ & Nonpublished \\
\hline $\mathrm{ABH} 2$ & ${ }^{99 \mathrm{~m}} \mathrm{Tc}$ & SPECT & NCT03546478 & I & 32 & 06/2018 & [106] \\
\hline HPArk2 & & & NCT04267900 & I & 30 & $02 / 2020$ & Nonpublished \\
\hline GE-226 & ${ }^{18} \mathrm{~F}$ & PET & NCT03827317 & Not applicable & 16 & $02 / 2019$ & Nonpublished \\
\hline
\end{tabular}

this tracer was further modified to achieve a better blood clearance and a higher background to tumor ratio. Another affibody that has been investigated in a clinical trial is ABY025 (ZHER2:2891) (NCT01216033). The ${ }^{111}$ In-labeled affibody demonstrated favourable biodistribution, safety, dosimetry and tumor targeting potential in patients with HER2positive metastatic breast cancer. In addition, high-contrast SPECT images were obtained within 4 to 24 h p.i., although the highest uptake in normal tissue was in the kidneys, followed by the liver and spleen [103]. In two further clinical studies the same affibody was examined with a ${ }^{68} \mathrm{Ga}$ label (NCT02095210, NCT01858116). By administering two different doses of peptide $(100 \mu \mathrm{g}$ or $500 \mu \mathrm{g})$ the effects on the uptake in tumors were investigated. PET images after 2 to $4 \mathrm{~h}$ p.i. showed that injection of $500 \mu \mathrm{g}{ }^{68} \mathrm{Ga}-\mathrm{ABY}-025$ led to better specificity and allowed differentiation between metastases with the HER2 expression levels of score $3+$ and score $2+[104,105] .{ }^{68} \mathrm{Ga}-\mathrm{ABY}-025$ is currently being investigated in a phase II/III clinical trial to determine the correlation between HER2 expression measured with ${ }^{68} \mathrm{Ga}-\mathrm{ABY}-025$ PET and standard histopathology from relevant tumor biopsies (NCT03655353). Administration of ${ }^{99 \mathrm{~m}}$ Tc-labeled HER2targeting affibody $\mathrm{ABH} 2$ in an open-label phase I clinical trial (NCT03546478) in HER2-positive breast cancer patients showed a specific binding (overall specificity $60 \%$ ) of the affibodies to their target molecule without noticeable adverse effects for the patient. After only 1.5 and $4.5 \mathrm{~h}$ p.i., highcontrast SPECT images were obtained, but the uptake of the radiotracer by the liver was so high $(\mathrm{T} / \mathrm{B}$ ratio $=21.9 \pm 3.5)$, that HER2-positive liver metastases could not be detected [106]. Another ${ }^{99 \mathrm{~m}}$ Tc-labeled affibody (HPArk2) is currently being investigated in an open label phase I clinical trial, but so far no results have been published (NCT04267900). In a further open label, non-randomised clinical trial, the efficacy of $\left[{ }^{18} \mathrm{~F}\right] \mathrm{GE}-226$ in determining HER2 expression level in patients with metastatic breast cancer is being investigated (NCT03827317). Furthermore, the pharmacokinetics of the affibody and the optimal time for the PET scan will be determined. However, no results have yet been reported for this study.

Despite the numerous advantages and features that make affibodies particularly suitable for molecular imaging, there are still some hurdles to overcome. For example, the low affinity of affibodies to the target is a major issue [27]. In addition, the design of the affibody molecules would have to be modified in order to reduce off-target interactions or background radioactivity [107]. However, the development of radioactively labeled affibodies is expensive and poses some challenges in scaling-up of the production process [27]. Moreover, the labeling approaches can lead to increased lipophilicity, which often leads to off-target interactions with normal tissue and binding to blood proteins [107]. A further disadvantage could be the bacterial origin of the protein scaffolds, as the risk of immunogenicity is increased after repeated therapeutic administration to patients [108]. Further clinical studies will be necessary to optimise the dose, time, sensitivity and specificity of these ligands, but also to improve the therapeutic application, which has so far been hampered by the short retention time of the affibody molecules in the blood.

\section{Nanobodies}

Most antibodies are Y-shaped and are composed of two heavy and two light polypeptide chains. In addition to these conventional antibodies, camelid species (i.e. Camelus dromedarius, Camelus bactrianus, Lama glama, Lama guanoco, Lama alpaca and Lama vicugna) and sharks produce heavy chain antibodies (HcAb, cf. Fig. 3) [109, 110]. Since the light chain is missing, the HcAbs bind to their antigen only by a single variable domain that is directly linked to the $\mathrm{Fc}$ domain $(\mathrm{CH} 2$ and $\mathrm{CH} 3)$ via a hinge region. The variable domain is called VHH in camelids and VNAR in sharks [111, 112]. The $\mathrm{VHH}$ in an $\mathrm{HcAb}$ is the structural and functional equivalent of 
Fig. 3 Schematic representation of a heavy chain antibody of dromedaries. Each variable domain $(\mathrm{VHH})$ of the HcAbs is connected to a hinge domain and further to $\mathrm{CH} 2$ and $\mathrm{CH} 3$ domains. The $\mathrm{CH} 2$ and $\mathrm{CH} 3$ domains form the Fc domain. The VHH domain represents the smallest intact functional antigen-binding region of HcAbs and is also called nanobody
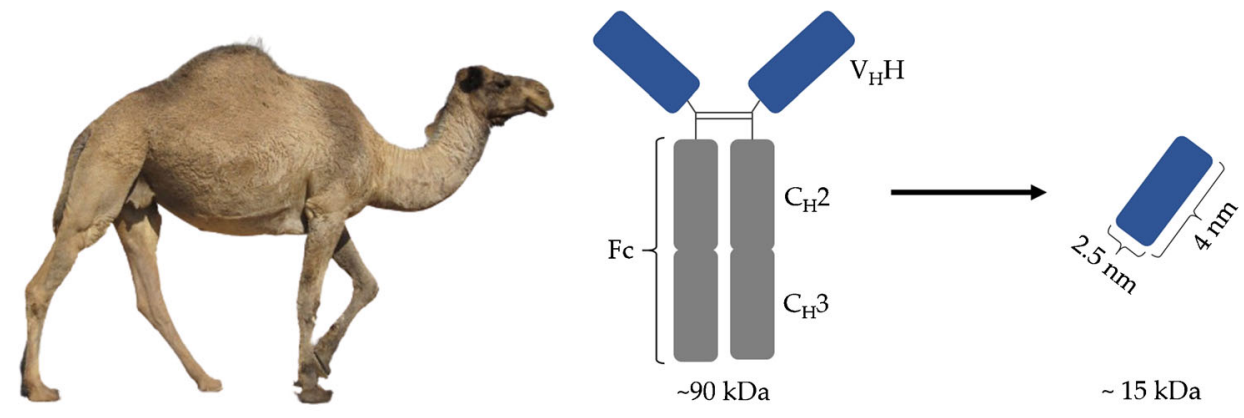

Dromedary
Heavy chain antibody
VHH/Nanobody the Fab fragment of conventional antibodies and is generally referred to as Nanobody ${ }^{\mathrm{TM}}$ or single-domain antibody (sdAb) due to its low molecular mass of only $15 \mathrm{kDa}$ (Fig. 3) [113]. The low molecular weight offers the advantage that the nanobodies can be eliminated via the kidney, which makes their biological half-life very short.

The crystal structures of several nanobodies showed that the scaffold of the VH and the VHH are identical. The scaffold of the prolate particle VHH with $2.5 \mathrm{~nm}$ diameter and about $4 \mathrm{~nm}$ height, consists of nine antiparallel $\beta$-strands forming two $\beta$-sheets stabilized by a conserved disulfide bridge [112, $114,115]$. Minor differences between the complementarity determining regions (CDR) of $\mathrm{VH}$ and $\mathrm{VHHs}$ explain for the strong antigen binding capacity of the camel-derived nanobodies [112]. For example, the CDR3 region of nanobodies is on average longer than that of $\mathrm{VH}$ and can be stabilized by an additional disulfide bond that connects the CDR3 to the adjacent CDR1 loop (common in VHH and VNAR) or to the CDR2 loop (common in Lama sdAbs) [116]. The elongated CDR3 region can form finger-like extensions that can extend into small cavities on the surface of the antigens which compensates for the absence of three other antigen-recognizing CDRs located in the light chain of conventional antibodies [117]. In addition, the hydrophobic to hydrophilic amino acid substitutions in the CDR2 region result in a structure with improved water solubility that is less susceptible to aggregation $[116,118]$. Despite these differences, nanobodies exhibit a high degree of sequence homology with the $\mathrm{VH}$ and are therefore considered to have a low immunogenic profile [119]. Nevertheless, the nanobodies can be further humanized by simple site-directed mutagenesis to reduce a possible immune response [120].

Nanobodies have many technological and biophysical advantages, making them superior to conventional antibodies in several areas. In addition to the high water solubility mentioned above, nanobodies are also very stable. Even after a 1-week incubation at $37{ }^{\circ} \mathrm{C}$, three of four nanobodies tested showed a binding activity of $100 \%$ and one nanobody $80 \%$ [121]. Melting temperature was set at over $60^{\circ} \mathrm{C}$, and even at temperatures up to $90^{\circ} \mathrm{C}$ the nanobodies showed their antigen- binding specificity, indicating high thermal stability [122, 123]. A high resistance of nanobodies to denaturing chemicals ( $8 \mathrm{M}$ urea, $3 \mathrm{M}$ guanidinium hydrochloride) has also been demonstrated. Immediately after diluting the chaotropic solution in water, the completely denatured nanobody folded back into its native form, which creates the conditions for sanitising the nanobodies and regenerating them several times [122]. Even exposure to non-physiological $\mathrm{pH}$ and elevated pressure were not able to impact the antigen binding capacity of nanobodies [124].

To obtain nanobodies, camelids are immunised with the antigen of interest, the DNA or with cells that express the antigen on their surface. After screening the nanobodies can then be easily expressed in microorganisms (Escherichia coli, Saccharomyces cerevisiae and Pichia pastoris), mammalian cells and plants due to their monomeric structure and the absence of post-translational modifications [93, 125, 126]. Production and selection advantages, such as the scalability of the production process or the easy cultivation in shake flasks, lead to high expression yields at low production prices [115].

\section{Radiolabeled nanobodies}

Due to their small size and high affinity, nanobodies are particularly suitable for penetrating tumor tissue and binding to the antigen with high specificity [127]. In order to use nanobodies as a theranostic tool, they must first be labeled with a suited radioactive nuclide. Since the biological halflife of the nanobodies is short, radionuclides with a short physical half-life can also be used. This would allow diagnostic scans to be taken just a few hours after tracer injection [128, 129].

Generally, due to the small size of nanobodies, an improved blood clearance compared to conventional antibodies could be verified: In several animal studies, it was shown that one hour after injection, less than $0.5 \%$ of the injected activity per gram tissue was present in the blood pool, resulting in a better signal-to-noise ratio for the specifically bound radiolabeled fragment and less toxic effects [92, 130, 131]. 
On the other hand, a rapid blood clearance could prevent the radiolabeled nanobody from circulating in the patient's blood and therefore only a small fraction of the administered nanobody reaches its target. Hence, multiple doses of the nanobody should be administered to achieve a high target load in vivo. The main disadvantage of using radiolabeled nanobodies as in vivo imaging probes is their accumulation in the kidneys, which is a consequence of their renal elimination. Due to their small size, which is below the renal threshold for glomerular filtration, the nanobodies are reabsorbed by the proximal tubules through the key endocytic receptor megalin so that they remain in the renal cortex. For this reason, nephrotoxicity can occur in renal cells due to the radiation dose. Also, the sensitivity for the detection of a specific molecular signal in the vicinity of the kidneys, such as in the pancreas, is severely limited $[132,133]$. Tchouate Gainkam et al. showed that the renal retention of the radiolabeled antiEGFR nanobody $\left({ }^{99 \mathrm{~m}} \mathrm{Tc}-7 \mathrm{C} 12\right)$ can be reduced by $36 \%$ by coinfusion from the plasma expander gelofusin [133, 134]. Gelofusin is a succinylated gelatin and increases the urinary excretion of proteins, especially those of low molecular weight [135]. A reduction of renal retention by about $45 \%$ was observed due to the additive effect of coinfusion of lysine and gelofusin with the radiolabeled nanobody ${ }^{99 \mathrm{~m}} \mathrm{Tc}-7 \mathrm{C} 12$ $[132,133]$. In addition, removal of the amino acid tag (His6) at the C-terminus can further reduce kidney retention and help to prevent immunogenic reactions $[131,136,137]$. However, apart from the accumulation of radiolabeled nanobodies in kidney and urine, biodistribution is antigen-specific, resulting in a high tumor to background ratio early after administration, allowing subsequent diagnostic scans $[138,139]$.

\section{Radiolabeled nanobodies in clinical studies (diagnostic and therapeutic approaches)}

Keyaerts et al. conducted the first clinical study with a radioactively labeled nanobody, the ${ }^{68} \mathrm{Ga}-\mathrm{NOTA}-2 \mathrm{Rs} 15 \mathrm{~d}$ (EudraCT 012001135-31) [140]. The nanobody 2Rs15d was identified by screening using technetium- $99 \mathrm{~m}$ label as the best nanobody for imaging HER2-positive tumors that does not interfere with the therapeutic agent trastuzumab [92]. The PET nuclide ${ }^{68} \mathrm{Ga}$ was chosen because it is cyclotron independent, nuclide generator based and with its short half-life of $68 \mathrm{~min}$ is suitable for use in humans. The NOTA derivative p-SCN-Bn-NOTA was applied as conjugated chelator enabling a fast and efficient ${ }^{68} \mathrm{Ga}$ radiolabeling at room temperature while its in vivo stability was high [131]. The results of the first clinical phase showed a favourable biodistribution with a high uptake of the tracer in the tumor (standardized uptake value $0.7-11.8$ ). Furthermore, rapid blood clearance was observed, with only $10 \%$ of the injected activity (IA) remaining in the blood $1 \mathrm{~h}$ after injection. In addition, a high tumor to background ratio was detected except for the kidney, liver and intestine regions. The optimal time for imaging was determined as $90 \mathrm{~min}$ after injection of the radiolabeled nanobody. The effective dose was $0.043 \mathrm{mSv} / \mathrm{MBq}$. No symptoms or signs of toxicity were observed after administration of ${ }^{68} \mathrm{Ga}$ anti-HER2 nanobody using $0.01-1 \mathrm{mg}$ of nanobody per injection [140], which is why it is considered safe and is currently being investigated in an open label nonrandomized monocenter phase II trial to evaluate its potential to detect brain metastases in breast cancer patients (EudraCT 2015-002328-24, NCT03331601) [141]. The correlation between image-based HER2 quantification after uptake of ${ }^{68} \mathrm{Ga}$ NOTA-2Rs15d in local or distant metastases of breast cancer patients and the results obtained by biopsy of the same lesion (NCT03924466) is under investigation in a further phase II clinical trial (VUBAR).

A phase I clinical trial (NCT04040686) is currently ongoing to evaluate the safety, dosimetry and efficacy of ${ }^{99 \mathrm{~m}} \mathrm{Tc}$ labeled anti-HER2 nanobodies in diagnostic imaging of HER2 in breast cancer patients. Subsequently, the results of molecular imaging will be compared with the results of HER2 expression by biopsy tissue immunohistochemistry and/or fluorescence in situ hybridization (FISH). The radionuclide ${ }^{99 \mathrm{~m}} \mathrm{Tc}$ is particularly suitable because it is available in almost every Nuclear Medicine unit via a generator system and the labeling process is simple and fast. In addition, the half-life ( $6 \mathrm{~h})$ fits to the fast blood clearance of nanobodies, allowing early diagnostic SPECT images with good contrast. This was proven in a preclinical study. Vaneycken et al. tested 38 different ${ }^{99 \mathrm{~m}} \mathrm{Tc}$ labeled nanobodies to find a lead compound. The nanobody ${ }^{99 \mathrm{~m}} \mathrm{Tc}-2 \mathrm{Rs} 15 \mathrm{~d}$ was found to be stable at least up to $24 \mathrm{~h}$ in PBS and serum and to interact specifically with the HER2 antigen. It also showed high tumor uptake (4.19 \pm $0.47 \% \mathrm{IA} / \mathrm{g}$ at $1.5 \mathrm{~h}$ p.i.), rapid blood clearance, low accumulation in non-target organs other than the kidneys and a high tumor to background ratio (tumor-to-muscle ratio $49.6 \pm 11.8$, tumor-to-blood ratio $16.4 \pm 3.6$ at $1 \mathrm{~h}$ p.i.) [92, 142].

Copper-64 (half-life $12.7 \mathrm{~h}$ ) is a hybrid beta emitter and has decay characteristics that allow for both, PET imaging and radioimmunotherapy. Lee et al. have investigated copper-64 radiolabeled MM-302 with simultaneous administration of trastuzumab regarding its enhanced permeability and retention effect in patients with HER2-positive metastatic breast cancer. The tumor accumulation of ${ }^{64} \mathrm{Cu}-\mathrm{MM}-302$ after 24 to $48 \mathrm{~h}$ ranged from 0.52 to $18.5 \% \mathrm{ID} / \mathrm{kg}$ and varied across lesions within a patient and between patients. Depositions in bone and brain lesions were also observed and a significant background uptake of ${ }^{64} \mathrm{Cu}-\mathrm{MM}-302$ in liver and spleen. Presumably, the discrepancy in the results led to the discontinuation of the phase I clinical trial (NCT02735798) [143, 144].

Iodine-131 decays with a half-life of 8.02 days with betaand gamma emissions and is used for diagnosis (SPECT) and especially therapy in Nuclear Medicine. One study investigated the radioiodination of the nanobody $5 \mathrm{~F} 7$ via the residual 
prosthetic group SGMIB [145]. In a previous study it was shown that the residualizing agent is particularly suitable for achieving good tumor retention and short renal retention [146, 147]. However, since the radiolabeled nanobody 5F7 competes with trastuzumab for binding to domain IV on HER2, the same radiolabeling was tested with the nanobody $2 \mathrm{Rs} 15 \mathrm{~d}$. In the preclinical study, ${ }^{131}$ I-SGMIB-2Rs15d was shown to specifically bind to HER 2 on a different epitope than trastuzumab. Although tumor uptake was lower (20.22 \pm $1.64 \% \mathrm{IA} / \mathrm{g}$ at $1 \mathrm{~h}$ p.i.) for ${ }^{131} \mathrm{I}$ SGMIB $2 \mathrm{Rs} 15 \mathrm{~d}$, a high tumor to background ratio, rapid blood clearance $(<2 \%$ IA/ total blood volume at $1 \mathrm{~h}$ p.i.) and short renal retention were observed. In addition, ${ }^{131}$ I-SGMIB-2Rs15d alone or in combination with trastuzumab was shown to significantly prolong median survival compared to animals treated with a ${ }^{131}$ I control nanobody (R3B23) (137.5 days vs. 93.5 days) [148]. A phase I clinical trial (NCT02683083) evaluated the safety, biodistribution and radiation dosimetry of ${ }^{131}$ I-SGMIB2Rs15d in healthy volunteers and patients with HER2positive breast cancer. Preliminary results showed a high tumor to background ratio, rapid blood clearance and elimination of unbound nanobodies via the kidney and no drugrelated adverse events after intravenous administration $(38 \mathrm{MBq} \pm 9 \mathrm{MBq})$. In addition, SPECT images showed that the nanobody was partially accumulated in metastases [149]. These promising results and favourable dosimetry would allow administration of therapeutic doses of ${ }^{131}$ I-SGMIB2Rs $15 \mathrm{~d}$ with a minimum risk of radiotoxicity.

An overview of to date clinically evaluated radiolabeled nanobodies with potential application in breast cancer patients is provided in Table 3.

\section{Radiolabeled nanobodies in preclinical studies (diagnostic and therapeutic)}

Because of its short half-life ( $\sim 110 \mathrm{~min})$ Fluor-18 is one of the preferred radionuclides for PET imaging. Thus, numerous ${ }^{18} \mathrm{~F}$ labeled nanobodies have been designed and evaluated as PET tracer. Despite of intensive studies, no useful HER2 targeting ${ }^{18} \mathrm{~F}$ labeled nanobody has been developed until now. In the first trials the HER2-targeting nanobodies $5 \mathrm{~F} 7$ and 2Rs15d were labeled with the prosthetic group $\left[{ }^{18} \mathrm{~F}\right]$-SFB $[150,151]$. Since the overall radiochemical yield of $\left[{ }^{18} \mathrm{~F}\right]-\mathrm{SFB}-2 \mathrm{Rs} 15 \mathrm{~d}$ was very low (5-15\%) [150] and the nanobody $5 \mathrm{~F} 7$ competes with trastuzumab for the HER2 binding site [152], the two nanobodies were labeled in another trial with $\left[{ }^{18} \mathrm{~F}\right]$-RL-I or $\left[{ }^{18} \mathrm{~F}\right]$-ADIBO via SPAAC $\left({ }^{18} \mathrm{~F}-\mathrm{RL}-\mathrm{II}-2 \mathrm{Rs} 15 \mathrm{~d}\right)$. With these tracers, excellent tumor targeting could be observed in HER2 positive cancer cells and xenotransplants, but the labeling procedure was too long and the radiolabeling yields were too low. In addition, unexpectedly high tracer accumulation in the liver, lung, spleen and kidney were observed [151-154]. Much better results were obtained in another study with the nanobody 2 Rs $15 \mathrm{~d}$ which was labeled with $\left[{ }^{18} \mathrm{~F}\right]$-TFPFN and $\left[{ }^{18} \mathrm{~F}\right]-A l F-N O T A-T z-T C O-G K$. The radiochemical yield and tumor to background ratios were high and the radiolabeled nanobody bound to the HER2 antigen with high affinity and high immunoreactivity. In addition, the renal uptake was reduced by more than 15 -fold compared to $\left[{ }^{18} \mathrm{~F}\right]-\mathrm{RL}-\mathrm{II}-2 \mathrm{Rs} 15 \mathrm{~d}$ and by about threefold compared to the level reported for $\left[{ }^{18} \mathrm{~F}\right]$-SFB-2Rs15d $[155,156]$.

Puttermans et al. have investigated ${ }^{111}$ In labeled 2 Rs $15 \mathrm{~d}$ via $\mathrm{p}-\mathrm{SCN}-\mathrm{Bn}-\mathrm{CHX}-\mathrm{A}^{\prime \prime}$-DTPA (DTPA*) as a theranostic

Table 3 Overview of human clinical trials of HER2 targeting radiolabeled nanobodies in breast cancer patients. Status April 2020

\begin{tabular}{|c|c|c|c|c|c|c|c|c|}
\hline Nanobody & Radioisotope & $\begin{array}{l}\text { Diagnostic/ } \\
\text { therapy }\end{array}$ & Trial no. & Phase & Patients & $\begin{array}{l}\text { First } \\
\text { posted }\end{array}$ & Outcome & Reference \\
\hline \multirow[t]{5}{*}{ 2Rs15d } & \multirow[t]{3}{*}{${ }^{68} \mathrm{Ga}$} & \multirow[t]{3}{*}{ PET } & $\begin{array}{l}\text { EudraCT } \\
\quad 2012-001135-31\end{array}$ & I & 20 & 2012 & $\begin{array}{l}\text { Favourable biodistribution, } \\
\text { high tumor to background } \\
\text { ratio, fast blood clearance } \\
\text { no signs of toxicity, urinary } \\
\text { bladder as dose limiting organ }\end{array}$ & {$[140]$} \\
\hline & & & $\begin{array}{l}\text { EudraCT } \\
\quad 2015-002328-24 \\
\text { NCT03331601 }\end{array}$ & II & 30 & $\begin{array}{l}07 / 2015 \\
11 / 2017\end{array}$ & Ongoing & Nonpublished \\
\hline & & & NCT03924466 & & 20 & $04 / 2019$ & Ongoing & Nonpublished \\
\hline & ${ }^{131} \mathrm{I}$ & $\begin{array}{l}\text { SPECT \& } \\
\text { Therapy }\end{array}$ & NCT02683083 & I & 9 & 02/2016 & $\begin{array}{l}\text { A high tumor to background rate, } \\
\text { fast blood clearance, no signs } \\
\text { of toxicity }\end{array}$ & [149] \\
\hline & ${ }^{99 \mathrm{~m}} \mathrm{Tc}$ & SPECT & NCT04040686 & I & 10 & 08/2019 & Ongoing & Nonpublished \\
\hline MM-302 & ${ }^{64} \mathrm{Cu}$ & PET and therapy & NCT02735798 & I & 0 & $04 / 2016$ & $\begin{array}{l}\text { Tumor accumulation vary } \\
\text { between } \\
\text { and within patients, background } \\
\text { uptake in liver and spleen } \\
\text { withdrawn }\end{array}$ & [143] \\
\hline
\end{tabular}


radiopharmaceutical in breast cancer mediated brain metastases. In the trial, twenty-one days after intracranial inoculation, HER2-positive SKOV3-Luc-IP1 and HER2-positive MDA$\mathrm{MB}^{2}{ }^{231} \mathrm{Br}$ tumor-bearing mice were injected intravenously with ${ }^{111}$ In-DTPA*-2Rs15d or ${ }^{111}$ In-DTPA*-trastuzumab. Outcomes of the trial showed that ${ }^{111}$ In-DTPA*-2Rs $15 \mathrm{~d}$ showed high tumor uptake in SKOV3.IP1 and MDA$\mathrm{MB}^{231} \mathrm{Br}$ tumor models $(2.2 \pm 0.4 \% \mathrm{IA} / \mathrm{g}$ and $4.52 \pm 1.31 \%$ $\mathrm{IA} / \mathrm{g}$ at $1 \mathrm{~h}$ p.i.). In addition, only very low accumulation in healthy tissue $(<1 \% \mathrm{IA} / \mathrm{g}$, except for kidney at $1 \mathrm{~h}$ p.i.) and fast renal clearance was observed. This was in contrast to the results obtained with ${ }^{111}$ In-DTPA*-trastuzumab. Here, only a low uptake of ${ }^{111}$ In-DTPA*-trastuzumab was observed in SKOV3.IP1 brain tumors. Thus, the study showed that the radiolabeled nanobody, in contrast to monoclonal antibodies, is able to pass the blood-brain barrier and is therefore the better option for molecular imaging of metastatic lesions in the brain [157].

In another trial, the first successful labeling of a nanobody with an $\alpha$-emitter, Actinium-225, was described. For this purpose, the nanobody $2 \mathrm{Rs} 15 \mathrm{~d}$ was radiolabeled with ${ }^{225} \mathrm{Ac}$ using the chelator p-SCN-Bn-DOTA. The nanobody ${ }^{225} \mathrm{Ac}$ DOTA-2Rs $15 \mathrm{~d}$ showed in vitro and in vivo a higher binding efficiency to HER2-overexpressing SKOV-3 cells than to low HER2-expressing MDA-MB-231 cells $(4.01 \%$ ID/g vs. $0.49 \% \mathrm{ID} / \mathrm{g}$ after $2 \mathrm{~h}$ ), indicating specific binding to the antigen and resulting in high tumor to normal tissue ratios. Moreover, coinjection of gelofusin reduced renal retention threefold, but in parallel a lower tumor uptake $(4.01 \pm 1.58 \%$ $\mathrm{ID} / \mathrm{g}$ at $2 \mathrm{~h}$ p.i.) and a slightly higher liver retention $(6.35 \% \mathrm{ID} /$ g vs. $4.41 \% \mathrm{ID} / \mathrm{g}$ without gelofusin at $2 \mathrm{~h}$ p.i.) were observed in SKOV-3 tumor-bearing mice [158]. A study investigating the therapeutic efficacy of this radioconjugate for brain metastatic breast cancer showed that administration of ${ }^{225} \mathrm{Ac}$ DOTA 2Rs15d alone or in combination with trastuzumab significantly increased the median survival in SKOV3.IP1 and MDA-MB-231Br brain tumor-bearing mice. In mice with intracranial SKOV3.IP1 tumors, the combined therapy even led to an extension of median survival by another 6.5 days compared to mice treated with ${ }^{225}$ Ac-DOTA-2Rs15d alone (29.5 days vs. 23 days). In addition, histopathological analyses showed no significant early toxicity, and renal retention was reduced by the simultaneous administration of $150 \mathrm{mg} / \mathrm{kg}$ gelofusin, making this radiolabeled nanobody a promising vehicle for targeted radionuclide therapy of HER2-positive brain lesions [157].

Choi et al. investigated the radiolabeling of the 5F7 nanobody with another $\alpha$-emitting radionuclide, the halogen Astatine-211 (7.2 h). For this purpose, the nanobody was labeled with the two prosthetic agents $\left[{ }^{211} \mathrm{At}\right]-\mathrm{SAGMB}$ or iso- $\left[{ }^{211} \mathrm{At}\right]-\mathrm{SAGMB}$ and was evaluated in SCID mice with subcutaneous BT474M1 xenografts. Although the radiochemical yield, purity and in vivo behaviour with respect to nonspecific accumulation in spleen and lungs were similar for both radioconjugates, isomer-dependent differences in the in vivo stability of these nanobodies were observed. The iso-conjugate showed a higher tumor uptake and binding affinity to the HER2 antigen. In addition, it showed a higher tumor to background ratio and shorter renal retention than $\left[{ }^{211} \mathrm{At}\right]-$ SAGMB-5F7. Thus, iso-[ $\left.{ }^{211} \mathrm{At}\right]-\mathrm{SAGMB}-5 \mathrm{~F} 7$ proved to be the more promising and was further investigated in another study on ${ }^{211}$ At-labeled nanobodies [159]. In this study, the iso-conjugate was compared with two other precursors, $\mathrm{m}$ MeATE and MSB, bound to the nanobody 2Rs15d. The [ $\left.{ }^{211} \mathrm{At}\right]-\mathrm{SAGMB}-2 \mathrm{Rs} 15 \mathrm{~d}$ was found to be the preferred compound for targeted alpha therapy due to its high tumor uptake $(8.90 \pm 2.79 \% \mathrm{ID} / \mathrm{g}$ at $1 \mathrm{~h}$ p.i.), low background signals and rapid renal excretion. In addition, the other two nanobodies could be excluded from further studies due to high accumulation in the stomach, spleen and lungs and their low in vivo stability. After metabolisation and deastatination of the less stable radioconjugates, the free ${ }^{211} \mathrm{At}$ is released back into the bloodstream, which leads to a high uptake in the aforementioned organs. Although the $\left[{ }^{211}\right.$ At]-SAGMB-2Rs15d showed high renal retention, this could be reduced by administration of gelofusin. This will be further investigated in a study on maximum tolerated dose, toxicity and therapeutic efficacy [160].

In a first attempt to label a nanobody with Lutetium177, four different bifunctional chelators (p-SCN-BnDOTA, DOTA-NHS ester, CHX-A"-DTPA or 1B4MDTPA) were compared to select the optimal chemical link between the radioisotope and a nanobody targeting HER2. Although high stability over time was achieved for all tested conjugates, the $2 \mathrm{Rs} 15 \mathrm{~d}$ conjugated with the $1 \mathrm{~B} 4 \mathrm{M}-$ DTPA chelator was found to be the best compound due to its high specific tumor uptake combined with the lowest background uptake [161]. In a subsequent study, this radioconjugate was investigated with a coinfusion of gelofusin in HER2-positive SKOV-3 tumor xenographted mice and compared to nanobodies with different $\mathrm{C}$ terminal amino acid tag sequences (Myc-His-tagged, Histagged and untagged). Between the four nanobodies investigated, the lowest renal retention was observed in the untagged ${ }^{177} \mathrm{Lu}$-DTPA-2Rs15d with simultaneous injection of $150 \mathrm{mg} / \mathrm{kg}$ gelofusin $(6.52 \pm 0.18 \%$ IA at $50 \mathrm{~min}$ p.i. $)$. Also, specific tumor uptake $(6.5 \pm 0.2 \% \mathrm{IA} / \mathrm{g}$ at $1 \mathrm{~h} \mathrm{p.i.)}$ and low background tissue and organ uptake $(<0.6 \% \mathrm{IA} / \mathrm{g}$ at $1 \mathrm{~h}$ p.i.) was observed for the untagged ${ }^{177} \mathrm{Lu}$-DTPA2Rs15d with simultaneous injection of $150 \mathrm{mg} / \mathrm{kg}$ gelofusin. In a comparative study, ${ }^{177} \mathrm{Lu}$-DTPAtrastuzumab supplied a 6-fold higher dose to the tumor than the untagged ${ }^{177}$ Lu-DTPA nanobody. On the other hand, ${ }^{177}$ Lu-DTPA-trastuzumab showed a significant retention of radioactivity in the lung, liver, spleen, bone and blood. Nevertheless, no evidence of renal toxicity 
could be found in histological analyses and the administration of ${ }^{177} \mathrm{Lu}$-DTPA-2Rs15d led to an almost complete inhibition of tumor growth [137].

\section{Outlook}

The many preclinical and clinical studies conducted in the recent years bear witness to the wide range of possible applications of antibody fragments such as affibodies and nanobodies, especially in the field of nuclear medicine. Their properties such as tissue permeability and rapid elimination from the blood make them ideal tools for targeted radiotherapy and molecular imaging. However, results of clinical studies show that nanobodies seem to be better suited for use as theranostatics in nuclear medicine due to their higher affinity to the target. One important point in theranostics is the choice of radionuclide. This should be stably linked to the nanobody and should not have a long half-life. The half-life of the radioisotope would then correlate with the short biological half-life of the nanobodies, thus avoiding high radiation exposure of the patients and allowing image acquisition within a couple of hours after application. In order to be able to use the therapeutic nanobodies in daily clinical practice, however, an appropriate blocker to protect the kidney from high radiation doses has to be researched beforehand or the nanobodies have to be modified in such a way that the renal retention is reduced. Not only the reduction of radiation exposure but also the reduction of toxicity in non-target tissues should be the aim of further investigations. The modification of nanobody to facilitate its passage through the blood-brain barrier is worth investigating, so that brain metastases can be better detected and treated in the future.

Introducing radiomics analyses of molecular imaging with radiolabelled HER2 targeting constructs (antibodies, affibodies or nanobodies) might further enhance the potential of this approach to support individualized management of breast cancer patients. Radiomic is defined as a set of methods for extracting and analysing quantitative data from biomedical images (features) to study individual tumor characteristics, clinical outcomes, and to develop computational models that can serve as tools for personalized diagnosis and treatment guidance [162].

\section{Conclusion}

Monoclonal antibodies and antibody drug conjugates represent the preferred treatment options for HER2 positive breast cancers due to their high specificity and affinity to the antigen. In contrast to the in situ determination of HER2 expression, the use of radiolabeled antibodies in vivo allows the assessment of tumor heterogeneity, tumor accessibility and the use of molecular targeted therapies. However, the use of antibodies in molecular imaging is impaired by slow blood clearance, associated with slow and low tumor uptake and with limited tumor penetration potential. Nanobodies, on the other hand, are characterised by their low molecular weight, high stability, strong antigen-binding affinity, water solubility and their ability to penetrate deeper into the tumor than monoclonal antibodies do (Fig. 4) [163, 164]. These properties make them a preferable vehicle for molecular imaging as well radioimmunotherapy.

In addition, they can be administered intravenously, orally, intraperitoneally or intratumoral due to their chemical stability including the ability to withstand harsh conditions, chaotropic agents and $\mathrm{pH}$ extremes. Their rapid clearance from the organism is advantageous when applying in molecular imaging. As a result, even with short-lived radioisotopes, high-contrast images can be recorded within a few hours post injection, enabling early diagnosis and reduced radiation exposure of patients. In therapy, the small size radiolabeled nanobodies show themselves superior to the radiolabeled monoclonal antibodies due to their higher specificity and their ability to penetrate the tumor. On the other hand, the monoclonal antibodies could be preferred for therapeutic approaches due to their longer residence time in the blood plasma and the associated higher lethal radiation doses delivered
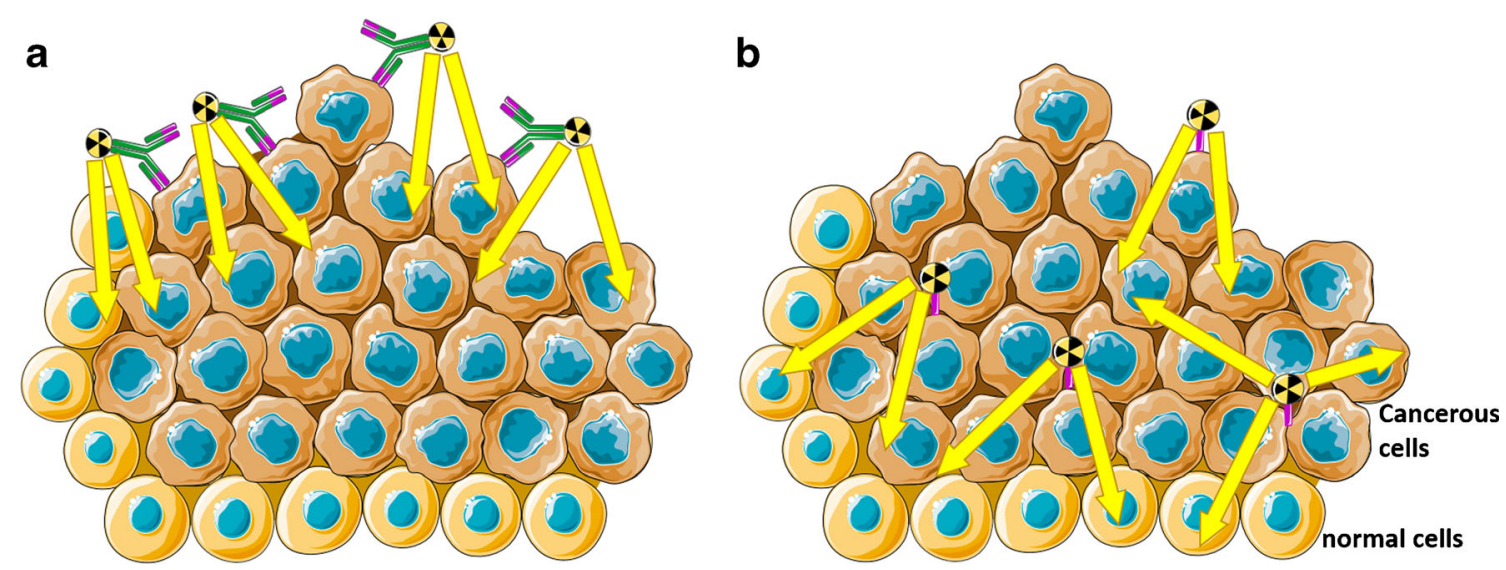

Fig. 4 Schematic representation of tumor penetration of radiolabeled monoclonal antibodies (a) compared to radiolabeled nanobodies (b) 
to the tumor. However, the attempts to use nanobodies as vehicles are still ongoing and so far show promising results and they could be well preferred over their monoclonal counterpart in the field of targeted radionuclide therapy. Not unlikely further elaborated drug delivery approaches might contribute to the success of nanobodies.

Authors' contributions Conceptualization, writing - original draft preparation BA, AM; writing - review and editing, all authors. All authors have read and agreed to the published version of the manuscript.

Funding Open Access funding enabled and organized by Projekt DEAL. BA is supported by an unrestricted grant from Nanomab technologies. This work was supported by the Deutsche Forschungsgemeinschaft (DFG) in the framework of the Research Training Group „Tumortargeted Drug Delivery" grant 331065168. AM received research funding from Deutsche Krebshilfe grant 70113779. FMM received research funding from the ITN INTRICARE of European Union's Horizon 2020 research and innovation program under the Marie Sklodowska Curie (grant 722609). .

\section{Compliance with ethical standards}

Conflicts of Interest Nicholas Wong and Hong Hoi Ting are employed by Nanomab Technologies. All other authors declare no conflict of interest with the content of this review.

Open Access This article is licensed under a Creative Commons Attribution 4.0 International License, which permits use, sharing, adaptation, distribution and reproduction in any medium or format, as long as you give appropriate credit to the original author(s) and the source, provide a link to the Creative Commons licence, and indicate if changes were made. The images or other third party material in this article are included in the article's Creative Commons licence, unless indicated otherwise in a credit line to the material. If material is not included in the article's Creative Commons licence and your intended use is not permitted by statutory regulation or exceeds the permitted use, you will need to obtain permission directly from the copyright holder. To view a copy of this licence, visit http://creativecommons.org/licenses/by/4.0/.

\section{References}

1. Bray F, Ferlay J, Soerjomataram I, Siegel RL, Torre LA, Jemal A. Global cancer statistics 2018: GLOBOCAN estimates of incidence and mortality worldwide for 36 cancers in 185 countries. CA Cancer J Clin. 2018;68(6):394-424. https://doi.org/10.3322/ caac. 21492

2. Hammond ME, Hayes DF, Dowsett M, Allred DC, Hagerty KL, Badve S, et al. American Society of Clinical Oncology/College Of American Pathologists guideline recommendations for immunohistochemical testing of estrogen and progesterone receptors in breast cancer. J Clin Oncol. 2010;28(16):2784-95. https://doi. org/10.1200/JCO.2009.25.6529.

3. Wolff AC, Hammond MEH, Hicks DG, Dowsett M, McShane LM, Allison KH, et al. Recommendations for Human Epidermal Growth Factor Receptor 2 Testing in Breast Cancer: American Society of Clinical Oncology/College of American Pathologists Clinical Practice Guideline Update. J Clin Oncol. 2013;31(31): 3997-+. https://doi.org/10.1200/Jco.2013.50.9984.
4. Slamon DJ, Clark GM, Wong SG, Levin WJ, Ullrich A, McGuire WL. Human breast cancer: correlation of relapse and survival with amplification of the HER-2/neu oncogene. Science. 1987;235(4785): 177-82. https://doi.org/10.1126/science.3798106.

5. Gesundheitswesen IfQuTi. Mammachirurgie Institut für Qualitätssicherung und Transparenz im Gesundheitswesen. 2018. 01.08.2018.

6. Ji H, Xuan Q, Nanding A, Zhang H, Zhang Q. The Clinicopathologic and Prognostic Value of Altered Chromosome 17 Centromere Copy Number in HER2 Fish Equivocal Breast Carcinomas. PLoS One. 2015;10(7): e0132824. https://doi.org/10.1371/journal.pone.0132824.

7. Ahn S, Woo JW, Lee K, Park SY. HER2 status in breast cancer: changes in guidelines and complicating factors for interpretation. J Pathol Transl Med. 2020;54(1):34-44. https://doi.org/10.4132/ jptm.2019.11.03.

8. Di Fiore P, Pierce J, Kraus M, Segatto O, King C, Aaronson S. erbB-2 is a potent oncogene when overexpressed in NIH/3T3 cells. Science. 1987;237(4811):178-82. https://doi.org/10.1126/ science. 2885917.

9. Guy CT, Webster MA, Schaller M, Parsons TJ, Cardiff RD, Muller WJ. Expression of the neu protooncogene in the mammary epithelium of transgenic mice induces metastatic disease. Proc Natl Acad Sci. 1992;89(22):10578-82. https://doi.org/10.1073/ pnas.89.22.10578

10. Hudziak RM, Schlessinger J, Ullrich A. Increased expression of the putative growth factor receptor p185HER2 causes transformation and tumorigenesis of NIH 3 T3 cells. Proc Natl Acad Sci U S A. 1987;84(20):7159-63. https://doi.org/10.1073/pnas.84.20.7159.

11. Pietras RJ, Arboleda J, Reese DM, Wongvipat N, Pegram MD, Ramos L, et al. HER-2 tyrosine kinase pathway targets estrogen receptor and promotes hormone-independent growth in human breast cancer cells. Oncogene. 1995;10(12):2435-46.

12. Wee P, Wang Z. Epidermal Growth Factor Receptor Cell Proliferation Signaling Pathways. Cancers (Basel). 2017;9(5). https://doi.org/10.3390/cancers9050052.

13. Slamon DJ, Leyland-Jones B, Shak S, Fuchs H, Paton V, Bajamonde A, et al. Use of chemotherapy plus a monoclonal antibody against HER2 for metastatic breast cancer that overexpresses HER2. N Engl J Med. 2001;344(11):783-92. https://doi.org/10.1056/NEJM200103153441101.

14. Seshadri R, Firgaira FA, Horsfall DJ, McCaul K, Setlur V, Kitchen P. Clinical significance of HER-2/neu oncogene amplification in primary breast cancer. The South Australian Breast Cancer Study Group. J Clin Oncol. 1993;11(10):1936-42. https://doi.org/10.1200/JCO.1993.11.10.1936.

15. Costa RLB, Czerniecki BJ. Clinical development of immunotherapies for HER2(+) breast cancer: a review of HER2-directed monoclonal antibodies and beyond. NPJ Breast Cancer. 2020;6: 10. https://doi.org/10.1038/s41523-020-0153-3.

16. Romond EH, Perez EA, Bryant J, Suman VJ, Geyer CE Jr, Davidson NE, et al. Trastuzumab plus adjuvant chemotherapy for operable HER2-positive breast cancer. N Engl J Med. 2005;353(16):1673-84. https://doi.org/10.1056/NEJMoa052122.

17. European Medicines Agency. Herceptin. https://www.ema. europa.eu/en/medicines/human/EPAR/herceptin. Accessed May 15, 2020.

18. Baselga J, Tripathy D, Mendelsohn J, Baughman S, Benz CC, Dantis L, et al. Phase II study of weekly intravenous recombinant humanized anti-p185HER2 monoclonal antibody in patients with HER2/neu-overexpressing metastatic breast cancer. J Clin Oncol. 1996;14(3):737-44. https://doi.org/10.1200/JCO.1996.14.3.737.

19. Cobleigh MA, Vogel CL, Tripathy D, Robert NJ, Scholl S, Fehrenbacher L, et al. Multinational study of the efficacy and safety of humanized anti-HER 2 monoclonal antibody in women who have HER2-overexpressing metastatic breast cancer that has progressed 
after chemotherapy for metastatic disease. J Clin Oncol. 1999;17(9): 2639-48. https://doi.org/10.1200/JCO.1999.17.9.2639.

20. Vogel CL, Cobleigh MA, Tripathy D, Gutheil JC, Harris LN, Fehrenbacher L, et al. Efficacy and safety of trastuzumab as a single agent in first-line treatment of HER2-overexpressing metastatic breast cancer. J Clin Oncol. 2002;20(3):719-26. https://doi. org/10.1200/JCO.2002.20.3.719.

21. Moja L, Tagliabue L, Balduzzi S, Parmelli E, Pistotti V, Guarneri $\mathrm{V}$, et al. Trastuzumab containing regimens for early breast cancer. Cochrane Database Syst Rev. 2012;4:CD006243. https://doi.org/ 10.1002/14651858.CD006243.pub2.

22. Osoba D, Slamon DJ, Burchmore M, Murphy M. Effects on quality of life of combined trastuzumab and chemotherapy in women with metastatic breast cancer. J Clin Oncol. 2002;20(14):3106-13. https://doi.org/10.1200/JCO.2002.03.090.

23. Le XF, Pruefer F, Bast RC Jr. HER2-targeting antibodies modulate the cyclin-dependent kinase inhibitor p27Kip1 via multiple signaling pathways. Cell Cycle. 2005;4(1):87-95. https://doi.org/ 10.4161/cc.4.1.1360

24. Beck A, Goetsch L, Dumontet C, Corvaia N. Strategies and challenges for the next generation of antibody drug conjugates. Nat Rev Drug Discov. 2017;16(5):315-37. https://doi.org/10.1038/nrd.2016. 268.

25. Bakhtiar R. Antibody drug conjugates. Biotechnol Lett. 2016;38(10): 1655-64. https://doi.org/10.1007/s10529-016-2160-x.

26. Staudacher AH, Brown MP. Antibody drug conjugates and bystander killing: is antigen-dependent internalisation required? $\mathrm{Br} \mathrm{J}$ Cancer. 2017;117(12):1736-42. https://doi.org/10.1038/bjc.2017.367.

27. Fu R, Carroll L, Yahioglu G, Aboagye EO, Miller PW. Antibody Fragment and Affibody ImmunoPET Imaging Agents: Radiolabelling Strategies and Applications. ChemMedChem. 2018;13(23):2466-78. https://doi.org/10.1002/cmdc.201800624.

28. Olafsen $\mathrm{T}, \mathrm{Wu} \mathrm{AM}$. Antibody vectors for imaging. Semin Nucl Med. 2010;40(3):167-81. https://doi.org/10.1053/j.semnuclmed. 2009.12.005.

29. Lewis Phillips GD, Li G, Dugger DL, Crocker LM, Parsons KL, Mai E, et al. Targeting HER2-positive breast cancer with trastuzumab-DM1, an antibody-cytotoxic drug conjugate. Cancer Res. 2008;68(22):9280-90. https://doi.org/10.1158/00085472.Can-08-1776.

30. Krop IE, Beeram M, Modi S, Jones SF, Holden SN, Yu W, et al. Phase I study of trastuzumab-DM1, an HER2 antibody-drug conjugate, given every 3 weeks to patients with HER2-positive metastatic breast cancer. J Clin Oncol. 2010;28(16):2698-704. https:// doi.org/10.1200/JCO.2009.26.2071.

31. Verma S, Miles D, Gianni L, Krop IE, Welslau M, Baselga J, et al. Trastuzumab emtansine for HER2-positive advanced breast cancer. N Engl J Med. 2012;367(19):1783-91. https://doi.org/10. 1056/NEJMoa1209124.

32. Krop IE, Kim SB, Martin AG, LoRusso PM, Ferrero JM, Badovinac-Crnjevic T, et al. Trastuzumab emtansine versus treatment of physician's choice in patients with previously treated HER2-positive metastatic breast cancer (TH3RESA): final overall survival results from a randomised open-label phase 3 trial. Lancet Oncol. 2017;18(6):743-54. https://doi.org/10.1016/S14702045(17)30313-3.

33. Ocana A, Amir E, Pandiella A. Dual targeting of HER2-positive breast cancer with trastuzumab emtansine and pertuzumab: understanding clinical trial results. Oncotarget. 2018;9(61):31915-9. https://doi.org/10.18632/oncotarget.25739.

34. Poon KA, Flagella K, Beyer J, Tibbitts J, Kaur S, Saad O, et al. Preclinical safety profile of trastuzumab emtansine (T-DM1): mechanism of action of its cytotoxic component retained with improved tolerability. Toxicol Appl Pharmacol. 2013;273(2): 298-313. https://doi.org/10.1016/j.taap.2013.09.003.
35. Shen K, Ma X, Zhu C, Wu X, Jia H. Safety and Efficacy of Trastuzumab Emtansine in Advanced Human Epidermal Growth Factor Receptor 2-Positive Breast Cancer: a Meta-analysis. Sci Rep. 2016;6:23262. https://doi.org/10.1038/srep23262.

36. Dieras V, Harbeck N, Budd GT, Greenson JK, Guardino AE, Samant M, et al. Trastuzumab emtansine in human epidermal growth factor receptor 2-positive metastatic breast cancer: an integrated safety analysis. J Clin Oncol. 2014;32(25):2750-7. https://doi.org/10.1200/JCO.2013.54.4999.

37. Ogitani Y, Aida T, Hagihara K, Yamaguchi J, Ishii C, Harada N, et al. DS-8201a, A Novel HER2-Targeting ADC with a Novel DNA Topoisomerase I Inhibitor, Demonstrates a Promising Antitumor Efficacy with Differentiation from T-DM1. Clin Cancer Res. 2016;22(20):5097-108. https://doi.org/10.1158/ 1078-0432.CCR-15-2822.

38. Nakada T, Sugihara K, Jikoh T, Abe Y, Agatsuma T. The latest research and development into the antibody-drug conjugate, [fam] trastuzumab deruxtecan (DS-8201a), for HER2 cancer therapy. Chem Pharm Bull. 2019;67(3):173-85. https://doi.org/10.1248/ cpb.c18-00744.

39. Nagai Y, Oitate M, Shiozawa H, Ando O. Comprehensive preclinical pharmacokinetic evaluations of trastuzumab deruxtecan (DS-8201a), a HER2-targeting antibody-drug conjugate, in cynomolgus monkeys. Xenobiotica. 2019;49(9):1086-96. https://doi. org/10.1080/00498254.2018.1531158.

40. Takegawa N, Nonagase Y, Yonesaka K, Sakai K, Maenishi O, Ogitani Y, et al. DS-8201a, a new HER2-targeting antibody-drug conjugate incorporating a novel DNA topoisomerase I inhibitor, overcomes HER2-positive gastric cancer T-DM1 resistance. Int J Cancer. 2017;141(8):1682-9. https://doi.org/10.1002/ijc.30870.

41. Ogitani Y, Hagihara K, Oitate M, Naito H, Agatsuma T. Bystander killing effect of DS-8201a, a novel anti-human epidermal growth factor receptor 2 antibody-drug conjugate, in tumors with human epidermal growth factor receptor 2 heterogeneity. Cancer Sci. 2016;107(7):1039-46. https://doi.org/10.1111/cas.12966.

42. Modi S, Saura C, Yamashita T, Park YH, Kim SB, Tamura K, et al. Trastuzumab deruxtecan in previously treated HER2positive breast cancer. N Engl J Med. 2020;382(7):610-21. https://doi.org/10.1056/NEJMoa1914510.

43. Lee BI, Park MH, Byeon JJ, Shin SH, Choi J, Park Y, et al. Quantification of an Antibody-Conjugated Drug in Fat Plasma by an Affinity Capture LC-MS/MS Method for a Novel Prenyl Transferase-Mediated Site-Specific Antibody-Drug Conjugate. Molecules. 2020;25(7). https://doi.org/10.3390/ molecules 25071515 .

44. Avilés P, Domínguez JM, Guillén MJ, Muñoz-Alonso MJ, Mateo C, Rodriguez-Acebes R, et al. MI130004, a novel antibody-drug conjugate combining trastuzumab with a molecule of marine origin, shows outstanding $<$ em $>$ In Vivo $<$ /em $>$ activity against HER2-expressing tumors. Mol Cancer Ther. 2018;17(4):786-94. https://doi.org/10.1158/1535-7163.mct-17-0795.

45. Martins CD, Kramer-Marek G, Oyen WJG. Radioimmunotherapy for delivery of cytotoxic radioisotopes: current status and challenges. Expert Opin Drug Deliv. 2018;15(2):185-96. https://doi. org/10.1080/17425247.2018.1378180.

46. Zaheer J, Kim H, Lee YJ, Kim JS, Lim SM. Combination Radioimmunotherapy Strategies for Solid Tumors. Int J Mol Sci. 2019;20(22). https://doi.org/10.3390/ijms20225579.

47. Langbein T, Weber WA, Eiber M. Future of theranostics: an outlook on precision oncology in nuclear medicine. J Nucl Med. 2019;60(Suppl 2):13S-9S. https://doi.org/10.2967/jnumed.118. 220566.

48. Debie P, Devoogdt N, Hernot S. Targeted Nanobody-Based Molecular Tracers for Nuclear Imaging and Image-Guided Surgery. Antibodies (Basel). 2019;8(1). https://doi.org/10.3390/ antib8010012. 
49. Xavier C, Devoogdt N, Hernot S, Vaneycken I, D'Huyvetter M, De Vos J, et al. Site-specific labeling of his-tagged nanobodies with (9)(9)mTc: a practical guide. Methods Mol Biol. 2012;911: 485-90. https://doi.org/10.1007/978-1-61779-968-6_30.

50. Massa S, Xavier C, De Vos J, Caveliers V, Lahoutte T, Muyldermans S, et al. Site-specific labeling of cysteine-tagged camelid single-domain antibody-fragments for use in molecular imaging. Bioconjug Chem. 2014;25(5):979-88. https://doi.org/ 10.1021/bc500111t.

51. Massa S, Xavier C, Muyldermans S, Devoogdt N. Emerging sitespecific bioconjugation strategies for radioimmunotracer development. Expert Opin Drug Deliv. 2016;13(8):1149-63. https://doi. org/10.1080/17425247.2016.1178235.

52. Morais M, Ma MT. Site-specific chelator-antibody conjugation for PET and SPECT imaging with radiometals. Drug Discov Today Technol. 2018;30:91-104. https://doi.org/10.1016/j.ddtec. 2018.10.002.

53. Massa S, Vikani N, Betti C, Ballet S, Vanderhaegen S, Steyaert J, et al. Sortase A-mediated site-specific labeling of camelid singledomain antibody-fragments: a versatile strategy for multiple molecular imaging modalities. Contrast Media Mol Imaging. 2016;11(5):328-39. https://doi.org/10.1002/cmmi.1696.

54. Perols A, Honarvar H, Strand J, Selvaraju R, Orlova A, Eriksson Karlström A, et al. Influence of DOTA Chelator Position on Biodistribution and Targeting Properties of $111 \mathrm{In}$-Labeled Synthetic Anti-HER2 Affibody Molecules. Bioconjug Chem. 2012;23(8):1661-70. https://doi.org/10.1021/bc3002369.

55. Gordon O, Ruiz-Bedoya CA, Ordonez AA, Tucker EW, Jain SK. Molecular imaging: a novel tool to visualize pathogenesis of infections in situ. mBio. 2019;10(5). https://doi.org/10.1128/mBio. 00317-19.

56. Abou DS, Ku T, Smith-Jones PM. In vivo biodistribution and accumulation of $89 \mathrm{Zr}$ in mice. Nucl Med Biol. 2011;38(5):67581. https://doi.org/10.1016/j.nucmedbio.2010.12.011.

57. Dijkers EC, Oude Munnink TH, Kosterink JG, Brouwers AH, Jager PL, de Jong JR, et al. Biodistribution of 89Zr-trastuzumab and PET imaging of HER2-positive lesions in patients with metastatic breast cancer. Clin Pharmacol Ther. 2010;87(5):586-92. https://doi.org/10.1038/clpt.2010.12.

58. Massicano AVF, Marquez-Nostra BV, Lapi SE. Targeting HER2 in nuclear medicine for imaging and therapy. Mol Imaging. 2018;17:1536012117745386. https://doi.org/10.1177/ 1536012117745386 .

59. Boros E, Holland JP, Kenton N, Rotile N, Caravan P. Macrocyclebased hydroxamate ligands for complexation and immunoconjugation of (89)zirconium for positron emission tomography (PET) Imaging. Chempluschem. 2016;81(3):274-81. https://doi.org/10.1002/cplu.201600003.

60. Dijkers EC, Kosterink JG, Rademaker AP, Perk LR, van Dongen GA, Bart J, et al. Development and characterization of clinicalgrade $89 \mathrm{Zr}$-trastuzumab for HER2/neu immunoPET imaging. J Nucl Med. 2009;50(6):974-81. https://doi.org/10.2967/jnumed. 108.060392 .

61. Bensch F, Brouwers AH, Lub-de Hooge MN, de Jong JR, van der Vegt B, Sleijfer S, et al. (89)Zr-trastuzumab PET supports clinical decision making in breast cancer patients, when HER2 status cannot be determined by standard work up. Eur J Nucl Med Mol Imaging. 2018;45(13):2300-6. https://doi.org/10.1007/s00259018-4099-8.

62. Gebhart G, Lamberts LE, Wimana Z, Garcia C, Emonts P, Ameye $\mathrm{L}$, et al. Molecular imaging as a tool to investigate heterogeneity of advanced HER2-positive breast cancer and to predict patient outcome under trastuzumab emtansine (T-DM1): the ZEPHIR trial. Ann Oncol. 2016;27(4):619-24. https://doi.org/10.1093/annonc/ mdv577.
63. Laforest R, Lapi SE, Oyama R, Bose R, Tabchy A, MarquezNostra BV, et al. [(89)Zr]Trastuzumab: evaluation of radiation dosimetry, safety, and optimal imaging parameters in women with HER2-positive breast cancer. Mol Imaging Biol. 2016;18(6):9529. https://doi.org/10.1007/s11307-016-0951-z.

64. Mortimer JE, Bading JR, Colcher DM, Conti PS, Frankel PH, Carroll MI, et al. Functional imaging of human epidermal growth factor receptor 2-positive metastatic breast cancer using $(64) \mathrm{Cu}$ DOTA-trastuzumab PET. J Nucl Med. 2014;55(1):23-9. https:// doi.org/10.2967/jnumed.113.122630.

65. Kurihara H, Hamada A, Yoshida M, Shimma S, Hashimoto J, Yonemori K, et al. (64)Cu-DOTA-trastuzumab PET imaging and HER2 specificity of brain metastases in HER2-positive breast cancer patients. EJNMMI Res. 2015;5:8. https://doi.org/10.1186/ s13550-015-0082-6.

66. Sasada S, Kurihara H, Kinoshita T, Yoshida M, Honda N, Shimoi $\mathrm{T}$, et al. Visualization of HER2-specific breast cancer intratumoral heterogeneity using (64)Cu-DOTA-trastuzumab PET. Eur J Nucl Med Mol Imaging. 2017;44(12):2146-7. https://doi.org/10.1007/ s00259-017-3781-6.

67. Bhusari P, Vatsa R, Singh G, Parmar M, Bal A, Dhawan DK, et al. Development of Lu-177-trastuzumab for radioimmunotherapy of HER2 expressing breast cancer and its feasibility assessment in breast cancer patients. Int J Cancer. 2017;140(4):938-47. https:// doi.org/10.1002/ijc.30500.

68. Li HK, Morokoshi Y, Daino K, Furukawa T, Kamada T, Saga T, et al. Transcriptomic signatures of auger electron radioimmunotherapy using nuclear targeting (111)in-trastuzumab for potential combination therapies. Cancer Biother Radiopharm. 2015;30(8):349-58. https://doi.org/10.1089/cbr.2015.1882.

69. Cai Z, Chattopadhyay N, Yang K, Kwon YL, Yook S, Pignol JP, et al. (111)In-labeled trastuzumab-modified gold nanoparticles are cytotoxic in vitro to HER2-positive breast cancer cells and arrest tumor growth in vivo in athymic mice after intratumoral injection. Nucl Med Biol. 2016;43(12):818-26. https://doi.org/10.1016/j. nucmedbio.2016.08.009.

70. Costantini DL, Bateman K, McLarty K, Vallis KA, Reilly RM. Trastuzumab-resistant breast cancer cells remain sensitive to the auger electron-emitting radiotherapeutic agent 111 In-NLStrastuzumab and are radiosensitized by methotrexate. J Nucl Med. 2008;49(9):1498-505. https://doi.org/10.2967/jnumed.108. 051771.

71. Yamaguchi H, Tsuchimochi M, Hayama K, Kawase T, Tsubokawa N. Dual-Labeled Near-Infrared/(99m)Tc Imaging probes using PAMAM-coated silica nanoparticles for the imaging of HER2-expressing cancer cells. Int J Mol Sci. 2016;17(7). https://doi.org/10.3390/ijms17071086.

72. Luo TY, Cheng PC, Chiang PF, Chuang TW, Yeh CH, Lin WJ. 188Re-HYNIC-trastuzumab enhances the effect of apoptosis induced by trastuzumab in HER2-overexpressing breast cancer cells. Ann Nucl Med. 2015;29(1):52-62. https://doi.org/10.1007/ s12149-014-0908-8.

73. Chen KT, Lee TW, Lo JM. In vivo examination of (188)Re(I)tricarbonyl-labeled trastuzumab to target HER2-overexpressing breast cancer. Nucl Med Biol. 2009;36(4):355-61. https://doi. org/10.1016/j.nucmedbio.2009.01.006.

74. Li GP, Zhang YF, Wang YX. 188Re-labeled herceptin inhibits proliferation of breast cancer cell line SKBR-3 in vitro. Nan Fang Yi Ke Da Xue Xue Bao. 2006;26(10):1455-7.

75. Luo TY, Tang IC, Wu YL, Hsu KL, Liu SW, Kung HC, et al. Evaluating the potential of 188Re-SOCTA-trastuzumab as a new radioimmunoagent for breast cancer treatment. Nucl Med Biol. 2009;36(1):81-8. https://doi.org/10.1016/j.nucmedbio.2008.10. 014.

76. Wickstroem K, Karlsson J, Ellingsen C, Cruciani V, Kristian A, Hagemann UB, et al. Synergistic effect of a HER2 targeted 
Thorium-227 conjugate in combination with olaparib in a BRCA2 deficient xenograft model. Pharmaceuticals (Basel). 2019;12(4). https://doi.org/10.3390/ph12040155.

77. Kameswaran M, Gota V, Ambade R, Gupta S, Dash A. Preparation and preclinical evaluation of (131) I-trastuzumab for breast cancer. J Labelled Comp Radiopharm. 2017;60(1):12-9. https://doi.org/10.1002/jlcr.3465.

78. Rasaneh S, Rajabi H, Hossein Babaei M, Johari Daha F. Toxicity of trastuzumab labeled $177 \mathrm{Lu}$ on MCF7 and SKBr3 cell lines. Appl Radiat Isot. 2010;68(10):1964-6. https://doi.org/10.1016/j. apradiso.2010.05.004.

79. Costantini DL, Chan C, Cai Z, Vallis KA, Reilly RM. (111)Inlabeled trastuzumab (Herceptin) modified with nuclear localization sequences (NLS): an Auger electron-emitting radiotherapeutic agent for HER2/neu-amplified breast cancer. J Nucl Med. 2007;48(8):1357-68. https://doi.org/10.2967/jnumed. 106.037937.

80. Ngo Ndjock Mbong G, Lu Y, Chan C, Cai Z, Liu P, Boyle AJ, et al. Trastuzumab labeled to high specific activity with (111)in by site-specific conjugation to a metal-chelating polymer exhibits amplified auger electron-mediated cytotoxicity on HER2positive breast cancer cells. Mol Pharm. 2015;12(6):1951-60. https://doi.org/10.1021/mp5007618.

81. Jiang D, Im HJ, Sun H, Valdovinos HF, England CG, Ehlerding EB, et al. Radiolabeled pertuzumab for imaging of human epidermal growth factor receptor 2 expression in ovarian cancer. Eur J Nucl Med Mol Imaging. 2017;44(8):1296-305. https://doi.org/10. 1007/s00259-017-3663-y.

82. Lam K, Chan C, Reilly RM. Development and preclinical studies of (64)Cu-NOTA-pertuzumab F(ab')2 for imaging changes in tumor HER2 expression associated with response to trastuzumab by PET/CT. MAbs. 2017;9(1):154-64. https://doi.org/10.1080/ 19420862.2016.1255389.

83. Marquez BV, Ikotun OF, Zheleznyak A, Wright B, Hari-Raj A, Pierce RA, et al. Evaluation of (89)Zr-pertuzumab in Breast cancer xenografts. Mol Pharm. 2014;11(11):3988-95. https://doi.org/10. 1021/mp500323d.

84. Persson M, Gedda L, Lundqvist H, Tolmachev V, Nordgren H, Malmstrom PU, et al. [177Lu]pertuzumab: experimental therapy of HER-2-expressing xenografts. Cancer Res. 2007;67(1):32631. https://doi.org/10.1158/0008-5472.CAN-06-2363.

85. Persson M, Tolmachev V, Andersson K, Gedda L, Sandstrom M, Carlsson J. [(177)Lu]pertuzumab: experimental studies on targeting of HER-2 positive tumour cells. Eur J Nucl Med Mol Imaging. 2005;32(12):1457-62. https://doi.org/10.1007/s00259005-1902-0.

86. Lobo ED, Hansen RJ, Balthasar JP. Antibody pharmacokinetics and pharmacodynamics. J Pharm Sci. 2004;93(11):2645-68. https://doi.org/10.1002/jps.20178.

87. Shadid M, Bowlin S, Bolleddula J. Catabolism of antibody drug conjugates and characterization methods. Bioorg Med Chem. 2017;25(12):2933-45. https://doi.org/10.1016/j.bmc.2017.04.010.

88. Jain RK, Baxter LT. Mechanisms of heterogeneous distribution of monoclonal antibodies and other macromolecules in tumors: significance of elevated interstitial pressure. Cancer Res. 1988;48(24 Pt 1):7022-32.

89. Beckman RA, Weiner LM, Davis HM. Antibody constructs in cancer therapy: protein engineering strategies to improve exposure in solid tumors. Cancer. 2007;109(2):170-9. https://doi.org/10. $1002 /$ cncr.22402.

90. Weinstein JN, van Osdol W. Early Intervention in Cancer Using Monoclonal Antibodies and Other Biological Ligands: Micropharmacology and the "Binding Site Barrier". Cancer Res. 1992;52(9 Supplement):2747s-51s.

91. Luque-Cabal M, Garcia-Teijido P, Fernandez-Perez Y, SanchezLorenzo L, Palacio-Vazquez I. Mechanisms Behind the
Resistance to Trastuzumab in HER2-Amplified Breast Cancer and Strategies to Overcome It. Clin Med Insights Oncol. 2016;10(Suppl 1):21-30. https://doi.org/10.4137/CMO.S34537.

92. Vaneycken I, Devoogdt N, Van Gassen N, Vincke C, Xavier C, Wernery U, et al. Preclinical screening of anti-HER2 nanobodies for molecular imaging of breast cancer. FASEB J. 2011;25(7): 2433-46. https://doi.org/10.1096/fj.10-180331.

93. Jovcevska I, Muyldermans S. The Therapeutic Potential of Nanobodies. BioDrugs. 2020;34(1):11-26. https://doi.org/10. 1007/s40259-019-00392-z.

94. Ritchie M, Tchistiakova L, Scott N. Implications of receptormediated endocytosis and intracellular trafficking dynamics in the development of antibody drug conjugates. MAbs. 2013;5(1): 13-21. https://doi.org/10.4161/mabs.22854.

95. Scott AM, Allison JP, Wolchok JD. Monoclonal antibodies in cancer therapy. Cancer Immun. 2012;12:14.

96. Puttemans J, Lahoutte T, D'Huyvetter M, Devoogdt N. Beyond the barrier: targeted radionuclide therapy in brain tumors and metastases. Pharmaceutics. 2019;11(8). https://doi.org/10.3390/ pharmaceutics11080376.

97. Friedman M, Stahl S. Engineered affinity proteins for tumourtargeting applications. Biotechnol Appl Biochem. 2009;53(Pt 1): 1-29. https://doi.org/10.1042/BA20080287.

98. Altai M, Perols A, Karlstrom AE, Sandstrom M, Boschetti F, Orlova A, et al. Preclinical evaluation of anti-HER2 Affibody molecules site-specifically labeled with 111 In using a maleimido derivative of NODAGA. Nucl Med Biol. 2012;39(4):518-29. https://doi.org/10.1016/j.nucmedbio.2011.10.013.

99. Engfeldt T, Orlova A, Tran T, Bruskin A, Widstrom C, Karlstrom $\mathrm{AE}$, et al. Imaging of HER2-expressing tumours using a synthetic Affibody molecule containing the $99 \mathrm{mTc}$-chelating mercaptoacetyl-glycyl-glycyl-glycyl (MAG3) sequence. Eur J Nucl Med Mol Imaging. 2007;34(5):722-33. https://doi.org/10. 1007/s00259-006-0266-4.

100. Orlova A, Tolmachev V, Pehrson R, Lindborg M, Tran T, Sandstrom M, et al. Synthetic affibody molecules: a novel class of affinity ligands for molecular imaging of HER2-expressing malignant tumors. Cancer Res. 2007;67(5):2178-86. https://doi. org/10.1158/0008-5472.CAN-06-2887.

101. Tolmachev V, Nilsson FY, Widstrom C, Andersson K, Rosik D, Gedda L, et al. 111In-benzyl-DTPA-ZHER2:342, an affibodybased conjugate for in vivo imaging of HER2 expression in malignant tumors. J Nucl Med. 2006;47(5):846-53.

102. Baum RP, Prasad V, Muller D, Schuchardt C, Orlova A, Wennborg A, et al. Molecular imaging of HER2-expressing malignant tumors in breast cancer patients using synthetic $111 \mathrm{In}$ - or 68Ga-labeled affibody molecules. J Nucl Med. 2010;51(6):8927. https://doi.org/10.2967/jnumed.109.073239.

103. Sorensen J, Sandberg D, Sandstrom M, Wennborg A, Feldwisch J, Tolmachev V, et al. First-in-human molecular imaging of HER2 expression in breast cancer metastases using the $111 \mathrm{In}-\mathrm{ABY}-025$ affibody molecule. J Nucl Med. 2014;55(5):730-5. https://doi.org/ 10.2967/jnumed.113.131243.

104. Sandstrom M, Lindskog K, Velikyan I, Wennborg A, Feldwisch J, Sandberg D, et al. biodistribution and radiation dosimetry of the anti-HER2 affibody molecule 68Ga-ABY-025 in breast cancer patients. J Nucl Med. 2016;57(6):867-71. https://doi.org/10. 2967/jnumed.115.169342.

105. Sorensen J, Velikyan I, Sandberg D, Wennborg A, Feldwisch J, Tolmachev V, et al. Measuring HER2-receptor expression in metastatic breast cancer using [68Ga]ABY-025 Affibody PET/CT. Theranostics. 2016;6(2):262-71. https://doi.org/10.7150/thno.13502.

106. Cai J, Li X, Mao F, Wang P, Luo Y, Zheng K, et al. Non-invasive monitoring of HER2 expression in breast cancer patients with 99mTc-Affibody SPECT/CT. Iran J Radiol. 2020;In Press. https://doi.org/10.5812/iranjradiol.96419. 
107. Tolmachev V, Orlova A. Affibody molecules as targeting vectors for PET imaging. Cancers (Basel). 2020;12(3). https://doi.org/10. 3390/cancers 12030651.

108. Feldwisch J, Tolmachev V. Engineering of affibody molecules for therapy and diagnostics. Methods Mol Biol. 2012;899:103-26. https://doi.org/10.1007/978-1-61779-921-1_7.

109. Greenberg AS, Avila D, Hughes M, Hughes A, McKinney EC, Flajnik MF. A new antigen receptor gene family that undergoes rearrangement and extensive somatic diversification in sharks. Nature. 1995;374(6518):168-73. https://doi.org/10.1038/ $374168 \mathrm{a} 0$.

110. Hamers-Casterman C, Atarhouch T, Muyldermans S, Robinson G, Hamers C, Songa EB, et al. Naturally occurring antibodies devoid of light chains. Nature. 1993;363(6428):446-8. https:// doi.org/10.1038/363446a0.

111. Holliger P, Hudson PJ. Engineered antibody fragments and the rise of single domains. Nat Biotechnol. 2005;23(9):1126-36. https://doi.org/10.1038/nbt1 142 .

112. Muyldermans S, Baral TN, Retamozzo VC, De Baetselier P, De Genst E, Kinne J, et al. Camelid immunoglobulins and nanobody technology. Vet Immunol Immunopathol. 2009;128(1-3):178-83. https://doi.org/10.1016/j.vetimm.2008.10.299.

113. Hu Y, Liu C, Muyldermans S. Nanobody-Based Delivery Systems for Diagnosis and Targeted Tumor Therapy. Front Immunol. 2017;8:1442. https://doi.org/10.3389/fimmu.2017. 01442 .

114. Decanniere K, Muyldermans S, Wyns L. Canonical antigenbinding loop structures in immunoglobulins: more structures, more canonical classes? J Mol Biol. 2000;300(1):83-91. https:// doi.org/10.1006/jmbi.2000.3839.

115. Revets H, De Baetselier P, Muyldermans S. Nanobodies as novel agents for cancer therapy. Expert Opin Biol Ther. 2005;5(1):11124. https://doi.org/10.1517/14712598.5.1.111.

116. Wesolowski J, Alzogaray V, Reyelt J, Unger M, Juarez K, Urrutia $\mathrm{M}$, et al. Single domain antibodies: promising experimental and therapeutic tools in infection and immunity. Med Microbiol Immunol. 2009;198(3):157-74. https://doi.org/10.1007/s00430009-0116-7.

117. De Genst E, Silence K, Decanniere K, Conrath K, Loris R, Kinne $\mathrm{J}$, et al. Molecular basis for the preferential cleft recognition by dromedary heavy-chain antibodies. Proc Natl Acad Sci U S A. 2006;103(12):4586-91. https://doi.org/10.1073/pnas. 0505379103 .

118. Muyldermans S, Cambillau C, Wyns L. Recognition of antigens by single-domain antibody fragments: the superfluous luxury of paired domains. Trends Biochem Sci. 2001;26(4):230-5. https:// doi.org/10.1016/s0968-0004(01)01790-x.

119. Muyldermans S. Nanobodies: natural single-domain antibodies. Annu Rev Biochem. 2013;82:775-97. https://doi.org/10.1146/ annurev-biochem-063011-092449.

120. Vincke C, Loris R, Saerens D, Martinez-Rodriguez S, Muyldermans S, Conrath K. General strategy to humanize a camelid single-domain antibody and identification of a universal humanized nanobody scaffold. J Biol Chem. 2009;284(5):3273-84. https://doi.org/10.1074/jbc.M806889200.

121. Arbabi Ghahroudi M, Desmyter A, Wyns L, Hamers R, Muyldermans S. Selection and identification of single domain antibody fragments from camel heavy-chain antibodies. FEBS Lett. 1997;414(3):521-6. https://doi.org/10.1016/s00145793(97)01062-4.

122. Dumoulin M, Conrath K, Van Meirhaeghe A, Meersman F, Heremans K, Frenken LG, et al. Single-domain antibody fragments with high conformational stability. Protein Sci. 2002;11(3):500-15. https://doi.org/10.1110/ps.34602.

123. Ewert S, Huber T, Honegger A, Pluckthun A. Biophysical properties of human antibody variable domains. J Mol Biol.
2003;325(3):531-53. https://doi.org/10.1016/s0022-2836(02) 01237-8.

124. De Vos J, Devoogdt N, Lahoutte T, Muyldermans S. Camelid single-domain antibody-fragment engineering for (pre)clinical in vivo molecular imaging applications: adjusting the bullet to its target. Expert Opin Biol Ther. 2013;13(8):1149-60. https://doi. org/10.1517/14712598.2013.800478.

125. Ismaili A, Jalali-Javaran M, Rasaee MJ, Rahbarizadeh F, Forouzandeh-Moghadam M, Memari HR. Production and characterization of anti-(mucin MUC1) single-domain antibody in tobacco (Nicotiana tabacum cultivar Xanthi). Biotechnol Appl Biochem. 2007;47(Pt 1):11-9. https://doi.org/10.1042/ BA20060071.

126. Arbabi-Ghahroudi M, Tanha J, MacKenzie R. Prokaryotic expression of antibodies. Cancer Metastasis Rev. 2005;24(4):501-19. https://doi.org/10.1007/s10555-005-6193-1.

127. Debie P, Lafont C, Defrise M, Hansen I, van Willigen DM, van Leeuwen FWB, et al. Size and affinity kinetics of nanobodies influence targeting and penetration of solid tumours. J Control Release. 2020;317:34-42. https://doi.org/10.1016/j.jconrel.2019. 11.014 .

128. Cortez-Retamozo V, Lauwereys M, Hassanzadeh Gh G, Gobert M, Conrath K, Muyldermans S, et al. Efficient tumor targeting by single-domain antibody fragments of camels. Int J Cancer. 2002;98(3):456-62. https://doi.org/10.1002/ijc.10212.

129. Vaneycken I, D'Huyvetter M, Hernot S, De Vos J, Xavier C, Devoogdt $\mathrm{N}$, et al. Immuno-imaging using nanobodies. Curr Opin Biotechnol. 2011;22(6):877-81. https://doi.org/10.1016/j. copbio.2011.06.009.

130. Broisat A, Hernot S, Toczek J, De Vos J, Riou LM, Martin S, et al. Nanobodies targeting mouse/human VCAM1 for the nuclear imaging of atherosclerotic lesions. Circ Res. 2012;110(7):927-37. https://doi.org/10.1161/CIRCRESAHA.112.265140.

131. Xavier C, Vaneycken I, D'Huyvetter M, Heemskerk J, Keyaerts $\mathrm{M}$, Vincke C, et al. Synthesis, preclinical validation, dosimetry, and toxicity of 68Ga-NOTA-anti-HER2 Nanobodies for iPET imaging of HER2 receptor expression in cancer. J Nucl Med. 2013;54(5):776-84. https://doi.org/10.2967/jnumed.112.111021.

132. Melis M, Bijster M, de Visser M, Konijnenberg MW, de Swart J, Rolleman EJ, et al. Dose-response effect of Gelofusine on renal uptake and retention of radiolabelled octreotate in rats with CA20948 tumours. Eur J Nucl Med Mol Imaging. 2009;36(12): 1968-76. https://doi.org/10.1007/s00259-009-1196-8.

133. Gainkam LO, Caveliers V, Devoogdt N, Vanhove C, Xavier C, Boerman $\mathrm{O}$, et al. Localization, mechanism and reduction of renal retention of technetium-99m labeled epidermal growth factor receptor-specific nanobody in mice. Contrast Media Mol Imaging. 2011;6(2):85-92. https://doi.org/10.1002/cmmi.408.

134. van Eerd JE, Vegt E, Wetzels JF, Russel FG, Masereeuw R, Corstens FH, et al. Gelatin-based plasma expander effectively reduces renal uptake of $111 \mathrm{In}$-octreotide in mice and rats. J Nucl Med. 2006;47(3):528-33.

135. ten Dam MA, Branten AJ, Klasen IS, Wetzels JF. The gelatinderived plasma substitute Gelofusine causes low-molecular-weight proteinuria by decreasing tubular protein reabsorption. J Crit Care. 2001;16(3):115-20. https://doi.org/10.1053/jcrc.2001.28787.

136. Chatalic KL, Veldhoven-Zweistra J, Bolkestein M, Hoeben S, Koning GA, Boerman OC, et al. A Novel ${ }^{111}$ In-Labeled AntiProstate-Specific Membrane Antigen Nanobody for Targeted SPECT/CT Imaging of Prostate Cancer. J Nucl Med. 2015;56(7):1094-9. https://doi.org/10.2967/jnumed.115.156729.

137. D'Huyvetter M, Vincke C, Xavier C, Aerts A, Impens N, Baatout $\mathrm{S}$, et al. Targeted radionuclide therapy with A $177 \mathrm{Lu}$-labeled antiHER2 nanobody. Theranostics. 2014;4(7):708-20. https://doi.org/ 10.7150/thno.8156. 
138. Olafsen T, Sirk SJ, Olma S, Shen CKF, Wu AM. ImmunoPET using engineered antibody fragments: fluorine-18 labeled diabodies for same-day imaging. Tumor Biol. 2012;33(3):669 77. https://doi.org/10.1007/s13277-012-0365-8.

139. Freise $\mathrm{AC}, \mathrm{Wu} \mathrm{AM}$. In vivo imaging with antibodies and engineered fragments. Mol Immunol. 2015;67(2 Pt A):142-52. https://doi.org/10.1016/j.molimm.2015.04.001.

140. Keyaerts M, Xavier C, Heemskerk J, Devoogdt N, Everaert H, Ackaert C, et al. Phase I Study of 68Ga-HER2-Nanobody for PET/CT Assessment of HER2 Expression in Breast Carcinoma. J Nucl Med. 2016;57(1):27-33. https://doi.org/10.2967/jnumed.115.162024.

141. Keyaerts M, Xavier C, Everaert H, Vaneycken I, Fontaine C, Decoster L, et al. 85TiPPhase II trial of HER2-PET/CT using 68Ga-anti-HER2 VHH1 for characterization of HER2 presence in brain metastases of breast cancer patients. Ann Oncol. 2019;30. https://doi.org/10.1093/annonc/mdz095.081.

142. Devoogdt N, Xavier C, Hernot S, Vaneycken I, D'Huyvetter M, De Vos J, et al. Molecular imaging using Nanobodies: a case study. Methods Mol Biol. 2012;911:559-67. https://doi.org/10. 1007/978-1-61779-968-6 35.

143. Lee H, Shields AF, Siegel BA, Miller KD, Krop I, Ma CX, et al. (64)Cu-MM-302 Positron emission tomography quantifies variability of enhanced permeability and retention of nanoparticles in relation to treatment response in patients with metastatic breast cancer. Clin Cancer Res. 2017;23(15):4190-202. https://doi.org/ 10.1158/1078-0432.CCR-16-3193.

144. Anselmo AC, Mitragotri S. Nanoparticles in the clinic: An update. Bioeng Transl Med. 2019;4(3):e10143. https://doi.org/10.1002/ btm2.10143.

145. Pruszynski M, Koumarianou E, Vaidyanathan G, Revets H, Devoogdt N, Lahoutte T, et al. Improved tumor targeting of anti-HER 2 nanobody through $\mathrm{N}$-succinimidyl 4guanidinomethyl-3-iodobenzoate radiolabeling. J Nucl Med. 2014;55(4):650-6. https://doi.org/10.2967/jnumed.113.127100.

146. Vaidyanathan G, Affleck DJ, Li J, Welsh P, Zalutsky MR. A polar substituent-containing acylation agent for the radioiodination of internalizing monoclonal antibodies: $\mathrm{N}$-succinimidyl 4-guanidinomethyl3-[131I]iodobenzoate ([131I]SGMIB). Bioconjug Chem. 2001;12(3): 428-38. https://doi.org/10.1021/bc0001490.

147. Vaidyanathan $\mathrm{G}$, Jestin E, Olafsen T, Wu AM, Zalutsky MR. Evaluation of an anti-p185(HER2) (scFv-C(H)2-C(H)3)2 fragment following radioiodination using two different residualizing labels: SGMIB and IB-Mal-D-GEEEK. Nucl Med Biol. 2009;36(6):67180. https://doi.org/10.1016/j.nucmedbio.2009.04.002.

148. D'Huyvetter M, De Vos J, Xavier C, Pruszynski M, Sterckx YGJ, Massa S, et al. (131)I-labeled Anti-HER2 Camelid sdAb as a Theranostic Tool in Cancer Treatment. Clin Cancer Res. 2017;23(21): 6616-28. https://doi.org/10.1158/1078-0432.CCR-17-0310.

149. Keyaerts M, Vos JD, Duhoux FP, Caveliers V, Fontaine C, Vanhoeij M, et al. Phase I results of CAM-H2: Safety profile and tumor targeting in patients. J Clin Oncol. 2018;36(15 suppl):e13017-e. https://doi.org/10.1200/JCO.2018. 36.15_suppl.e13017.

150. Xavier C, Blykers A, Vaneycken I, D'Huyvetter M, Heemskerk J, Lahoutte T, et al. (18)F-nanobody for PET imaging of HER2 overexpressing tumors. Nucl Med Biol. 2016;43(4):247-52. https://doi.org/10.1016/j.nucmedbio.2016.01.002.

151. Vaidyanathan G, McDougald D, Choi J, Koumarianou E, Weitzel D, Osada T, et al. Preclinical Evaluation of 18F-Labeled AntiHER2 Nanobody Conjugates for Imaging HER2 Receptor Expression by Immuno-PET. J Nucl Med. 2016;57(6):967-73. https://doi.org/10.2967/jnumed.115.171306.

152. Zhou Z, Vaidyanathan G, McDougald D, Kang CM, Balyasnikova I, Devoogdt N, et al. Fluorine-18 Labeling of the HER2-Targeting Single-Domain Antibody 2Rs15d Using a Residualizing Label and
Preclinical Evaluation. Mol Imaging Biol. 2017;19(6):867-77. https:// doi.org/10.1007/s11307-017-1082-X.

153. Vaidyanathan G, McDougald D, Choi J, Pruszynski M, Koumarianou E, Zhou Z, et al. N-Succinimidyl 3-((4-(4-[(18)F]fluorobutyl)-1H-1,2, 3-triazol-1-yl)methyl)-5-(guanidinomethyl)ben zoate ([(18)F]SFBTMGMB): a residualizing label for (18)F-labeling of internalizing biomolecules. Org Biomol Chem. 2016;14(4):1261-71. https://doi.org/10.1039/c5ob02258d.

154. Zhou Z, Chitneni SK, Devoogdt N, Zalutsky MR, Vaidyanathan G. Fluorine-18 labeling of an anti-HER2 VHH using a residualizing prosthetic group via a strain-promoted click reaction: Chemistry and preliminary evaluation. Bioorg Med Chem. 2018;26(8):1939-49. https://doi.org/10.1016/j.bmc.2018.02.040.

155. Zhou Z, McDougald D, Devoogdt N, Zalutsky MR, Vaidyanathan G. Labeling Single Domain Antibody Fragments with Fluorine-18 Using 2,3,5,6-Tetrafluorophenyl 6-[(18)F]Fluoronicotinate Resulting in High Tumor-to-Kidney Ratios. Mol Pharm. 2019;16(1):214-26. https://doi.org/10.1021/acs.molpharmaceut.8b00951.

156. Zhou Z, Devoogdt N, Zalutsky MR, Vaidyanathan G. An Efficient Method for Labeling Single Domain Antibody Fragments with (18)F Using Tetrazine- Trans-Cyclooctene Ligation and a Renal Brush Border Enzyme-Cleavable Linker. Bioconjug Chem. 2018;29(12): 4090-103. https://doi.org/10.1021/acs.bioconjchem.8b00699.

157. Puttemans J, Dekempeneer Y, Eersels JL, Hanssens H, Debie P, Keyaerts M, et al. Preclinical Targeted alpha- and beta(-)Radionuclide Therapy in HER2-Positive Brain Metastasis Using Camelid Single-Domain Antibodies. Cancers (Basel). 2020;12(4). https://doi.org/10.3390/cancers 12041017.

158. Pruszynski M, D'Huyvetter M, Bruchertseifer F, Morgenstern A, Lahoutte T. Evaluation of an Anti-HER2 Nanobody Labeled with (225)Ac for Targeted alpha-Particle Therapy of Cancer. Mol Pharm. 2018;15(4):1457-66. https://doi.org/10.1021/acs. molpharmaceut.7b00985.

159. Choi J, Vaidyanathan G, Koumarianou E, Kang CM, Zalutsky MR. Astatine-211 labeled anti-HER2 5F7 single domain antibody fragment conjugates: radiolabeling and preliminary evaluation. Nucl Med Biol. 2018;56:10-20. https://doi.org/10.1016/j. nucmedbio.2017.09.003.

160. Dekempeneer Y, Back T, Aneheim E, Jensen H, Puttemans J, Xavier C, et al. Labeling of Anti-HER2 Nanobodies with Astatine-211: Optimization and the Effect of Different Coupling Reagents on Their in Vivo Behavior. Mol Pharm. 2019;16(8): 3524-33. https://doi.org/10.1021/acs.molpharmaceut.9b00354.

161. D'Huyvetter M, Aerts A, Xavier C, Vaneycken I, Devoogdt N, Gijs M, et al. Development of $177 \mathrm{Lu}$-nanobodies for radioimmunotherapy of HER2-positive breast cancer: evaluation of different bifunctional chelators. Contrast Media Mol Imaging. 2012;7(2):254-64. https://doi.org/10.1002/cmmi.491.

162. Lee SH, Park H, Ko ES. Radiomics in breast imaging from techniques to clinical applications: a review. Korean J Radiol. 2020;21(7):779-92. https://doi.org/10.3348/kjr.2019.0855.

163. Bannas P, Lenz A, Kunick V, Well L, Fumey W, Rissiek B, et al. Molecular imaging of tumors with nanobodies and antibodies: Timing and dosage are crucial factors for improved in vivo detection. Contrast Media Mol Imaging. 2015;10(5):367-78. https:// doi.org/10.1002/cmmi.1637.

164. Fang T, Lu X, Berger D, Gmeiner C, Cho J, Schalek R, et al. Nanobody immunostaining for correlated light and electron microscopy with preservation of ultrastructure. Nat Methods. 2018;15(12): 1029-32. https://doi.org/10.1038/s41592-018-0177-x.

Publisher's note Springer Nature remains neutral with regard to jurisdictional claims in published maps and institutional affiliations. 